Global Liquidity, House Prices, and the Macroeconomy: Evidence from Advanced and Emerging Economies 


\title{
Global Liquidity, House Prices, and the Macroeconomy: Evidence from Advanced and Emerging Economies
}

\author{
Ambrogio Cesa-Bianchi, Luis Felipe Cespedes, and \\ Alessandro Rebucci
}




\title{
IMF Working Paper
}

\author{
Research Department
}
Global Liquidity, House Prices, and the Macroeconomy: Evidence from Advanced and Emerging Economies

\section{Prepared by Ambrogio Cesa-Bianchi, Luis Felipe Cespedes, and Alessandro Rebucci ${ }^{1}$}

\author{
Authorized for distribution by Prakash Loungani
}

January 2015

\section{This Working Paper should not be reported as representing the views of the IMF. The views expressed in this Working Paper are those of the author(s) and do not necessarily represent those of the IMF or IMF policy. Working Papers describe research in progress by the author(s) and are published to elicit comments and to further debate.}

\begin{abstract}
In this paper we first compare house price cycles in advanced and emerging economies using a new quarterly house price data set covering the period 1990-2012. We find that house prices in emerging economies grow faster, are more volatile, less persistent and less synchronized across countries than in advanced economies. We also find that they correlate with capital flows more closely than in advanced economies. We then condition the analysis on an exogenous change to a particular component of capital flows. We find that a global liquidity shock, identified by aggregating bank-to-bank cross border flows and by using the external instrumental variable approach of Stock and Watson (2012) and Mertens and Ravn (2013), has a much stronger impact on house prices and consumption in emerging markets than in advanced economies. In our empirical model, holding house prices or the exchange rate constant in response to this shock tends to dampen its effects on consumption in emerging economies.
\end{abstract}

JEL Classification Numbers: Capital flows, emerging markets, global liquidity, house prices, external instrumental variables

Keywords: C32, E44, F44

Author's E-Mail Address: ambrogio.cesa-bianchi@bankofengland.co.uk; 1 lfcespedes@uai.cl; arebucci@jhu.edu

\footnotetext{
${ }^{1}$ Bank of England; Universidad Adolfo Ibanez, and Johns Hopkins University, respectively. We would like to thank Saleem Bahaj, Philippe Bracke, Valentina Bruno, Giancarlo Corsetti, Andrea Ferrero, Peter Karadi, Ken Kuttner, Jean Imbs, Prakash Loungani, Andy Powell, Konstantinos Theodoridis, and seminar participants at the Dallas FED, American University, the XVII Workshop in International Economics and Finance, the Bundesbank, and the IMF for helpful comments and suggestions.
} 


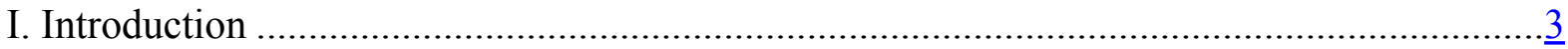

II. A New Global House Price Data Set ......................................................................

III. House Price Cycles in Advance and Emerging Economies..........................................

IV. Co-movement between House Prices and the Macroeconomy ….................................11

V. Global Liquidity and Its Impact on the Macroeconomy ...........................................14

VI. Global Liquidity, House Prices and Consumption Dynamics .................................... 17

A. The Empirical Model .........................................................................

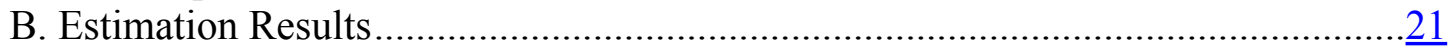

VII. Inspecting the Transmission Mechanism ..........................................................

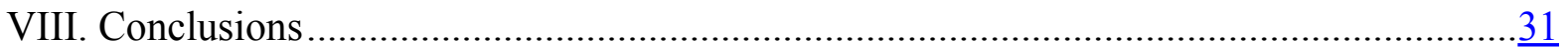

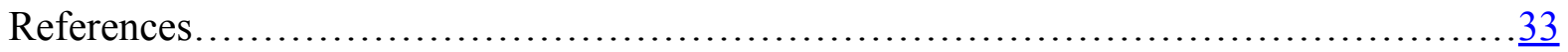

Tables

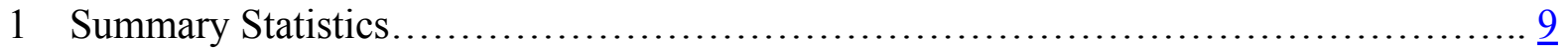

2. Instrumental Variable Estimation......................................... $\underline{22}$

Figures

1. Real House Prices.............................................................. 7

2. Real House Price Inflation.................................................. $\frac{11}{13}$

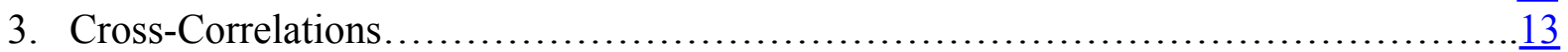

4. Global Liquidity......................................................

5. Global Liquidity Shock - Cholesky Identification............................ 24

6. Global Liquidity Shock - IV Identification................................... $\underline{26}$

7. Global Liquidity Shock - Housing Channel................................ $\frac{28}{30}$

8. Global Liquidity Shock - Exchange Rate Channel............................. $\underline{30}$

Appendix A. Data Sources.........................................................

Appendix B. Robustnes....................................................... $\frac{38}{41}$

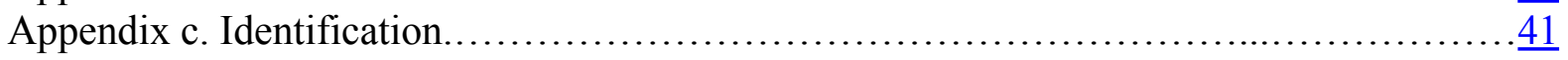




\section{INTRODUCTION}

Housing is a quintessential non-tradable durable good, and the non-tradable sector has often been at the center of financial crises. Booms in the non-tradable sector fuelled by excessive credit expansions and overvalued exchange rates were at the core of the many banking and currency crises that emerging market economies experienced in the 1990s and early 2000s (Claessens, Kose, Laeven, and Valencia, 2013). A similar mechanism played an important role in the recent banking and external crises in southern Europe (Bruno and Shin, 2015). These crises were often triggered by external shocks, such as a reversal of capital flows associated with tighter financing conditions in the United States and other advanced economies. But they were amplified by falling collateral values that contracted households and firms' borrowing capacity in a procyclical manner.

At the same time, over the past 20 years or so — in Asia and other emerging markets first, and in the United States and other advanced economies more recently — capital has been abundant and highly mobile, while the set of profitable investment opportunities has been limited. On this backdrop, policy makers worldwide have worried for some time now about the side effects of large and volatile capital flows. Indeed, while some blamed (at least in part) the United States housing and financial collapse on the glut of Asian saving that exerted downward pressure on US long-term interest rates, emerging economies in Latin America and Asia tended to blame excessive exchange rate appreciations, asset price bubbles and overheating on the monetary policy stimulus enacted by the United States in response to the global financial crisis.

In this paper we compare house price behavior in advanced and emerging economies using a new, quarterly data set on emerging market house prices that we assembled for this purpose. We first document a new set of stylized facts for emerging markets, showing that house price inflation tends to behave like consumption growth, which is non-tradable internationally to a significant degree. By comparison, equity prices behave more like GDP, which has a much larger tradable component. In particular, we show that in emerging markets house price inflation is higher, more volatile, less persistent and less synchronized across countries than in advanced economies. We also show that house price inflation is more correlated with capital flows in emerging countries.

Led by this latter fact, we then build an empirical model of house prices and capital flows in which we can identify an exogenous change to a specific component of total gross flows, i.e. "global liquidity". Global liquidity, which we interpret in a broad sense as the international supply of credit, was a quantitatively sizable portion of total cross-border flows in the run up to the global financial crisis (Bruno and Shin, 2015). Although its share of total flows fell after the crisis (Shin, 2013, Ahmed, Curcuru, Warnock, and Zlate, 2014), it remains closely associated with debt 
flows and international financial conditions more generally (Rey, 2013).

In this model we identify a global liquidity shock by aggregating bank-to-bank cross-border credit flows across all sending and receiving countries in our sample and by using the external instrumental variable approach of Stock and Watson (2012) and Mertens and Ravn (2013). ${ }^{1}$ By aggregating cross-border lending across all sending and receiving countries we rule out that countryspecific factors affect it within a quarter. By using the external instruments identification approach, we can rule out that demand factors that are common among all countries in the sample may affect the aggregate measure.

The estimation results show that a global liquidity shock affects house prices, consumption, and the current account in emerging economies much more than in advanced economies. These effects are also associated with a weaker interest rate and exchange rate response in emerging markets.

In an attempt to interpret our empirical findings, we finally explore the role of collateral valuation effects linked to house price and exchange rate changes. In general equilibrium models of housing and the macroeconomy — see for example Iacoviello (2005), Monacelli (2009), and Liu, Wang, and Zha (2013) — collateral constraints can amplify the response of consumption and investment to ordinary business cycle shocks. Shocks, via their impact on house prices, affect the value of collateral and in turn determine the borrowing capacity of households and firms. The real exchange rate plays a similar role in the partial equilibrium model of global liquidity of Bruno and Shin (2015) and in general equilibrium models of balance sheet effects (e.g., Cespedes, Chang, and Velasco, 2004, 2012, Gabaix and Maggiori, 2014).

To accomplish this, we re-estimate the effect of the same global liquidity shock, but keeping either house prices or the exchange rate constant in the model. When we hold house prices constant, in the case of advanced economies, the main difference between the baseline and the counterfactual is the consumption response to the shock; in the case of emerging economies, instead, the main difference is the exchange rate and the current account response. In addition, when we close the exchange rate channel, we find that house prices become more stable in emerging markets, while they become more volatile in advanced economies.

We interpret this evidence as suggesting that house price movements amplify the response to global liquidity shocks in both advanced and emerging economies, but possibly through different mechanisms. In advanced economies, arguably by boosting the value of housing collateral and hence supporting more household borrowing as predicted by the housing models with domestic borrowing constraints mentioned above; in emerging markets, by generating a lower default risk

\footnotetext{
${ }^{1}$ This identification strategy uses instrumental variables to isolate the component of the VAR reduced-form residuals that are due to the structural shock of interest. Appendix C describes it in more detail.
} 
and a more appreciated exchange rate that support the international borrowing capacity of the economy.

The paper relates to several strands of literature. A few papers focused on house prices behavior over the business cycle. Andre (2010) and Hirata, Kose, Otrok, and Terrones (2012) document the cyclical behavior of house prices and their relation to the macroeconomy for advanced economies. Igan and Loungani (2012), Claessens, Kose, and Terrones (2012), and Cesa-Bianchi (2013) also consider emerging markets in their analyses. Unlike the previous literature, we compare advanced and emerging economies systematically by using samples of comparable country size and quarterly data over a period covering both the emerging market crises of the 1990s and the global financial crisis.

A second strand of literature has explored the relation between capital flows and house prices in an attempt to gauge the role of the so called "global external imbalances" during the global financial crisis. Using data for advanced economies, Laibson and Mollerstrom (2010), Favilukis, Kohn, Ludvigson, and Nieuwerburgh (2012), Adam, Kuang, and Marcet (2012) and Ferrero (2012) provide evidence of a robust association between real house price appreciations and a widening of the current account deficit. Similarly, using a panel data of both advanced and emerging economies, Aizenman and Jinjarak (2009) find that lagged changes in current account deficits are associated with an appreciation of real house prices. Gete (2009) and Sa, Towbin, and Wieladek (2014) investigate the causal link from the current account and capital flows to house prices in VAR models for advanced economies. Relative to this strand of literature, not only we compare systematically advanced and emerging economies, but we also suggest a novel approach to identifying a capital account shock. Indeed, as far as we are aware of, this is the first application of the external instrumental variable approach to a capital flow shock.

The paper also relates to the ongoing debate on the side-effects of (and prospective exit from) exceptionally loose monetary policies that advanced economies enacted in response to the global financial crisis. Landau (2013) stresses the importance of understanding the consequences of advanced economies' monetary policies on cross-border movements of liquid assets, which are driven more and more by global risk appetite and, to a lesser extent, by interest rate differentials. Similarly, Rey (2013) highlights the impact of monetary policy in the United States on the nature and the direction of international capital flows which, in turn, affect credit conditions and asset price behavior. Relative to these studies, we build an empirical model of global liquidity and investigate the impact of an exogenous change in such a variable on both house prices and the broader macroeconomy.

The rest of the paper is organized as follow. Section 2 describes our new data set. Section 3 compares house price characteristics in the two group of countries. Section 4 looks at the association 
with the broader macroeconomy and capital flows in particular. Section 5 discusses the concept of global liquidity and its links to house prices. Section 6 explores the causal link from global liquidity to consumption and house prices in a panel VAR model. Section 7 discusses and tries to interpret our empirical findings by means of a simple counterfactual exercise. Three appendices report additional information on the data and the details of the analysis.

\section{A New Global House Price data Set}

A contribution of the paper is the construction of a new, quarterly house price data set for 33 emerging markets with a minimum coverage from the early 2000s to 2012:Q4 for all countries except Mexico and Morocco, thus providing house price series with at least 40 observations. $^{2}$ This information is combined with data for 24 advanced economies from the OECD house price database. Therefore, the data set that we will use in the analysis covers 57 countries and more than 95 percent of world GDP. ${ }^{3}$

Our new data set on emerging economies uses information from the OECD house price database, the BIS property price data set, the Federal Reserve of Dallas international house price database, national central banks, national statistical offices, and academic and policy publications on housing markets. ${ }^{4}$ Relative to its main building blocks - i.e., the OECD, the BIS, and the Federal Reserve of Dallas data sets- we extend the time coverage of 12 series and include 9 additional country indices. Specifically, we extended the existing series for China, Estonia, Hong Kong, Hungary, Indonesia, Lithuania, Malaysia, Philippines, Poland, Slovakia, Slovenia, and Thailand; and we collected data for Argentina, Brazil, Chile, Colombia, Czech Republic, India, Serbia, Taiwan, and Uruguay. In the process, we also extended the coverage for three advanced economies, namely Austria, Greece, and Malta.

The coverage of existing indices is extended by extrapolating backward newer series with historical data. For countries for which there exists a quarterly house price index, we extrapolate backward with the growth rate of the historical series. To make sure that the two series are comparable we use any overlapping period to evaluate the extrapolation. ${ }^{5}$ For a few countries for which there exists only an annual index, we first interpolate the annual data, and then extrapolate backward the quarterly series. To interpolate annual data, we simply assume that house prices grow at a constant rate within the year.

\footnotetext{
${ }^{2}$ Mexico and Morocco house price series are slightly shorter. We use data for these two countries only in the first, descriptive part of our analysis.

${ }^{3}$ The data set is available at: https://sites.google.com/site/ambropo/ and https://sites.google.com/site/arebucci.

${ }^{4}$ Appendix A provides details on the definitions and sources of the data.

${ }^{5}$ This part of the analysis is not reported but is available from the authors on request.
} 
(a) Advanced Economies

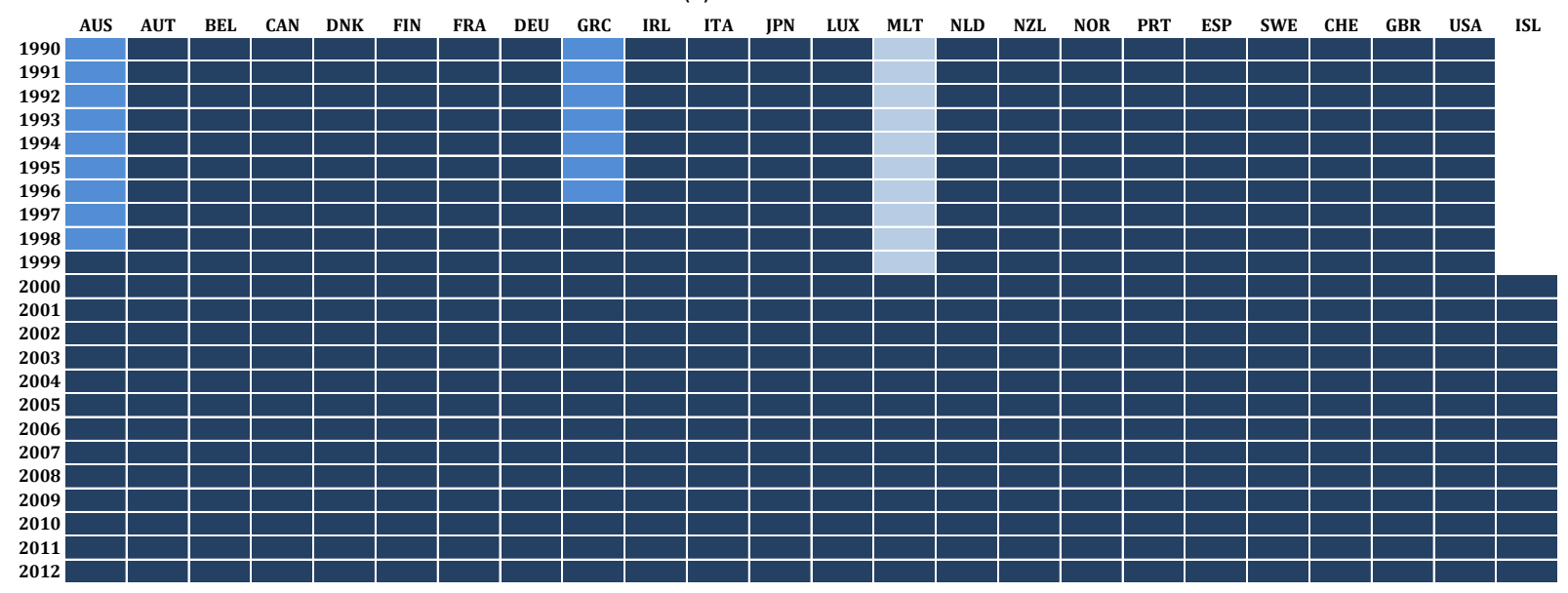

(b) Emerging Economies

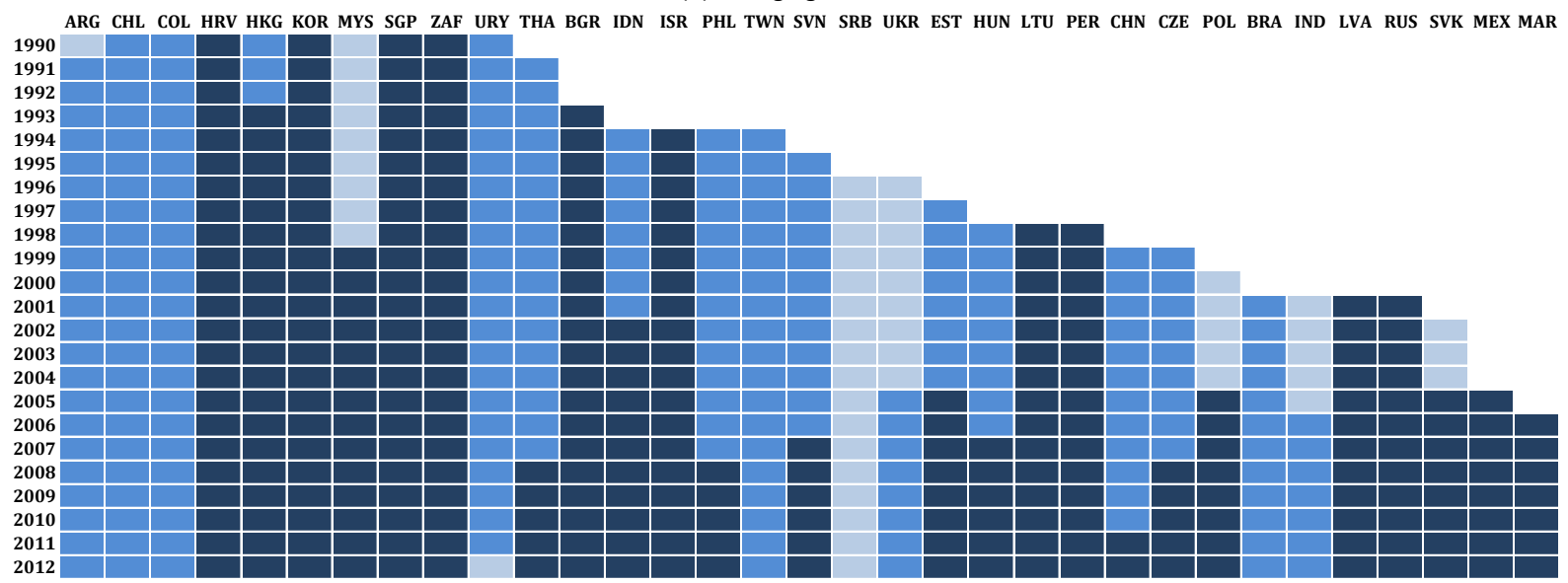

Figure 1 REAL HOUSE PRICES - DATA MAP. The chart shows the time coverage of country-specific house price series in our dataset, with different colors depending on the source of the data used. Dark blue cells are OECD, BIS or Dallas FED international quarterly house price data; medium blue cells are other sources at quarterly frequency; light blue cells are other sources at annual or semi-annual frequency. The legend for the country codes is as follows: Argentina (ARG), Australia (AUS), Austria (AUT), Belgium (BEL), Brazil (BRA), Bulgaria (BGR), Canada (CAN), Chile (CHL), China (CHN), Colombia (COL), Croatia (HRV), Czech Republic (CZE), Denmark (DNK), Estonia (EST), Finland (FIN), France (FRA), Germany (DEU), Greece (GRC), Hong Kong (HKG), Hungary (HUN), Iceland (ISL), India (IND), Indonesia (IDN), Ireland (IRL), Israel (ISR), Italy (ITA), Japan (JPN), Korea (KOR), Latvia (LVA), Lithuania (LTU), Luxembourg (LUX), Malaysia (MYS), Malta (MLT), Mexico (MEX), Morocco (MAR), Netherlands (NLD), New Zealand (NZL), Norway (NOR), Peru (PER), Philippines (PHL), Poland (POL), Portugal (PRT), Russia (RUS), Serbia (SRB), Singapore (SGP), Slovakia (SVK), Slovenia (SVN), South Africa (ZAF), Spain (ESP), Sweden (SWE), Switzerland (CHE), Taiwan (TWN), Thailand (THA), Ukraine (UKR), United Kingdom (GBR), United States (USA).

The resulting data set is an unbalanced panel of 57 quarterly time series with varying coverage from 1990:Q1 to 2012:Q4. Figure 1 provides a visual impression of the data coverage. The top panel describes advanced economies (AEs). The bottom panel describes emerging markets 
(EMs). The darker areas reflect the coverage of the OECD, BIS and Dallas FED data sets. The lighter areas represent either additional countries or series extended backward over time with quarterly data. The lightest areas refer to series extended backward with annual or semi-annual data. As we can see, with the only exception of Iceland, all advanced economies are covered from $1990 .{ }^{6}$ The coverage for emerging market economies is more varied, with 10 countries starting in the 1990 (compared to 23 AEs), a few more countries starting in mid-1990s, and only 3 countries with less than 40 quarterly observations.

The specific definition and the sources of our house price indices are listed in Appendix A. As it is well known, unfortunately, available house price indices do not follow a harmonized definition and methodology. As a result they are very heterogeneous. Even within the OECD house price database, for instance, indices may differ along a number of dimensions. In our data set, some series are median while others are averages prices; most series are not quality adjusted; some refer to nationally representative type of properties while other are for specific property type; some may refer to transaction prices while others are valuations or offer prices; some refer to new houses and others to all sales. Importantly, some series are national indices, while a few are indices for a major city.

Controlling for this heterogeneity in our analysis of the data is a difficult task. We note however that, in the few instances in which we have both national house price indices and their individual city components (i.e., for the United States, Canada, Australia, and the United Kingdom), or more granular information on different type of properties within a given city (i.e., London, Moscow, Geneva, Paris, Hong Kong, Singapore, Beijing, Shanghai, Sydney, and Tokyo), we find a relatively high correlation among the different indices within a country or a city. Thus, to the extent to which domestic housing markets are driven by common country factors, using a particular house price indicator to study the relation between housing and the macroeconomy should be less problematic.

\section{House Price Cycles In Advanced And Emerging Economies}

In this section we compare some time series properties of our house price indices in advanced (AEs) and emerging market economies (EMs). Throughout the analysis, we will focus on real house price inflation. ${ }^{7}$

\footnotetext{
${ }^{6}$ The OECD house price database covers these countries since 1970 . Very few emerging market series, however, starts in the 1970 s or the 1980 s.

${ }^{7}$ We plot the level of all real house prices series in an extended appendix available on the authors' web sites. All series are seasonally adjusted and then deflated with a country-specific CPI (also seasonally adjusted). The seasonal adjustment is performed on the quarterly growth rate of the nominal house price series using the X12 procedure with
} 
Table 1 reports key statistics for the log-difference of real house prices, real equity prices, real private consumption, and real GDP for the two group of countries. ${ }^{8}$ The statistics are computed country by country, over the longest period available for both equity and house prices, starting in 1990:Q1. Thus, the sample period for this exercise is 1990:Q1-2012:Q4. We then average across countries within each group. We report average, median, standard deviation, auto correlation, and pairwise correlation. ${ }^{9}$

Table 1 Summary STATISTICs (1990-2012)

(a) Advanced Economies

\begin{tabular}{lrrrr}
\hline \hline & House Prices & Equity Prices & Consumption & GDP \\
\hline Mean & $0.4 \%$ & $0.1 \%$ & $0.5 \%$ & $0.5 \%$ \\
Median & $0.5 \%$ & $1.3 \%$ & $0.6 \%$ & $0.6 \%$ \\
St. Dev. & $1.9 \%$ & $10.1 \%$ & $1.1 \%$ & $1.1 \%$ \\
Auto Corr. & 0.6 & 0.4 & 0.2 & 0.3 \\
Pairwise Corr. & 0.2 & 0.7 & 0.2 & 0.3 \\
\hline \hline
\end{tabular}

(b) Emerging Markets

\begin{tabular}{lrrrr}
\hline \hline & House Prices & Equity Prices & Consumption & GDP \\
\hline Mean & $0.7 \%$ & $0.5 \%$ & $1.1 \%$ & $0.9 \%$ \\
Median & $0.6 \%$ & $1.4 \%$ & $1.2 \%$ & $1.2 \%$ \\
St. Dev. & $4.8 \%$ & $15.0 \%$ & $2.4 \%$ & $2.1 \%$ \\
Auto Corr. & 0.3 & 0.3 & 0.1 & 0.3 \\
Pairwise Corr. & 0.1 & 0.5 & 0.1 & 0.2 \\
\hline \hline
\end{tabular}

Note. Averages of country-specific statistics within group. All variables are in log-difference and seasonally adjusted. House prices and equity prices are deflated with CPI (also seasonally adjusted). Real private consumption and real GDP are from the national accounts. Sample period is longest series available for house prices since 1990:Q1.

House price inflation is higher, less persistent, and much more volatile in emerging markets than in advanced economies. Over the period 1990-2012, real house prices grew 2.8 and $1.6 \%$ per year in AEs and EMs, respectively. This is consistent with the faster growth of output and consumption in emerging economies. Like consumption, which has a significant non-tradable component, house prices in EMs are more than twice as volatile as in AEs, at about $5 \%$ per quarter. GDP and equity prices are also more volatile in EMs than in AEs, but not to the same extent. To see it in another way, note that house price volatility is about a third of equity price volatility in the additive option.

${ }^{8} \mathrm{~A}$ summary of the definitions and sources of the other data series used is provided in Appendix A.

${ }^{9}$ Country-specific results are reported in the extended appendix. 
EMs, but it is only about a fifth of it in advanced economies. The persistence of house price inflation and consumption growth is much lower in EMs and it is comparable to that of equity prices. GDP and equity prices, in contrast, are more or less equally persistent in the two groups of countries.

Table 1 also reports a measure of synchronization across countries, the pairwise correlation. ${ }^{10}$ This statistics shows that house price inflation is not synchronized across countries. Again, their pairwise correlation is comparable to that of consumption, both in advanced and emerging economies, and is much lower than that of equity prices or even GDP, pointing to the relatively less tradable nature of housing as an asset class. In emerging markets, synchronization is even lower than in advanced economies. ${ }^{11}$

These stylized facts are robust to changing the sample in a number of ways. As we show in Appendix B, they remain essentially unchanged if we drop the crisis period from 2007:Q1 to 2012:Q4 (Table B.1), if we drop all the interpolated data from the analysis (Table B.2), or if we change the starting date of the analysis to 1995 (Table B.3), the same starting point for our conditional analysis of the data in the second part of the paper.

Figure 2 provides a visual characterization of the house price cycle in the two groups of economies. It plots the average real house price inflation across countries (solid line) over the period 1990:Q12012:Q4 together with the 25/75 interquartile range (shaded area). This is a simple way to estimate a common factor in our unbalanced panel of house price series (see for instance Forni and Reichlin, 1998, Pesaran, 2006). Superimposed is also a 5-year moving average of the common factor (dashed line) to smooth shorter-run fluctuations.

The picture shows that the two house price inflation cycles display little commonality over this period. The chart also shows how much more volatile house prices are in EMs, and how in general the cycle in AEs seems to anticipate that in EMs. The global expansion that started in 1985 peaked in 1989-1990 in advanced economies, while it lasted until 1994-95 in emerging markets. ${ }^{12}$ Subsequently, emerging markets went through a prolonged period of declining house price inflation - and even deflation - that ended only in the early-2000s, a period in which emerging economies experienced numerous financial crises. Coincidentally, the end of the boom in

\footnotetext{
${ }^{10}$ The pairwise correlation of a variable $x$ in country $i$ is the average of the contemporaneous correlation between $x_{i}$ and $x_{j}$ for all $j$. Synchronization can also be measured as the importance of the first principal component computed on all $x_{\mathbf{i}}$. Principal component analysis requires a balanced data set. In the case of an unbalanced panel, the pairwise correlation has the advantage of using the maximum amount of information available.

${ }^{11}$ These results are consistent with those reported by Hirata, Kose, Otrok, and Terrones (2012) for AEs, and by Cesa-Bianchi (2013) for both AEs and EMs. Note however that both papers stress the increase in the co-movement over time.

${ }^{12}$ The beginning of this global expansion is identifiable once we extend backward the same picture based on the same data for advanced economies and the few emerging markets indices that goes back sufficiently in time.
} 
(a) Advanced Economies

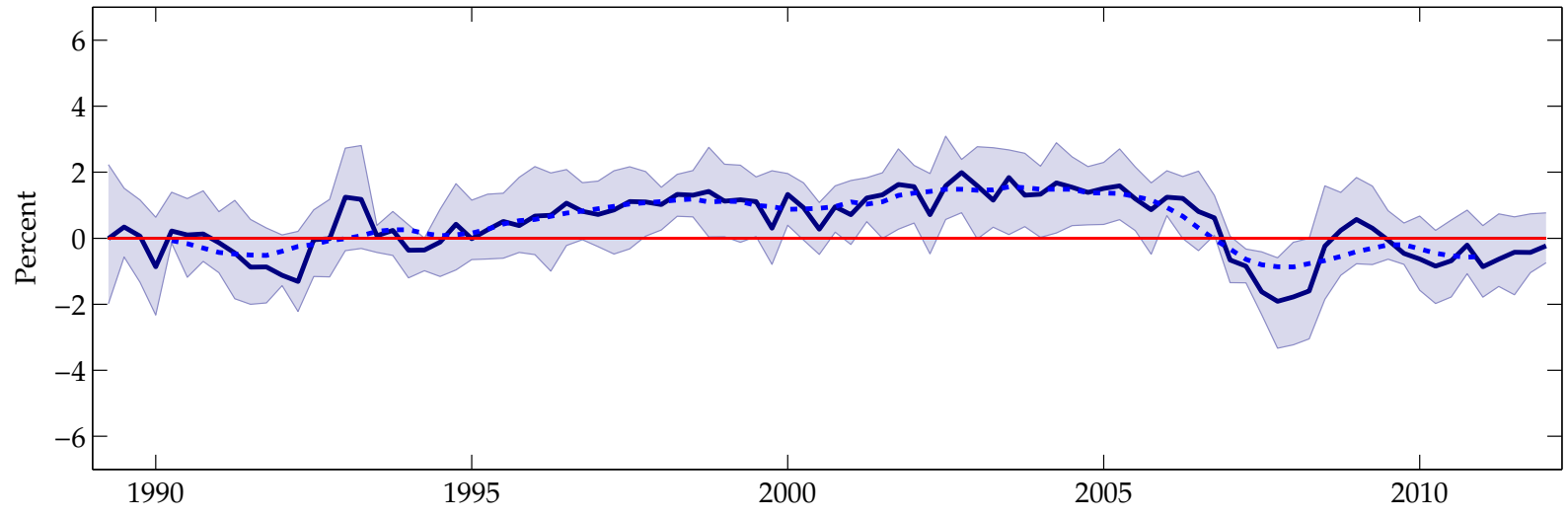

(a) Emerging Economies

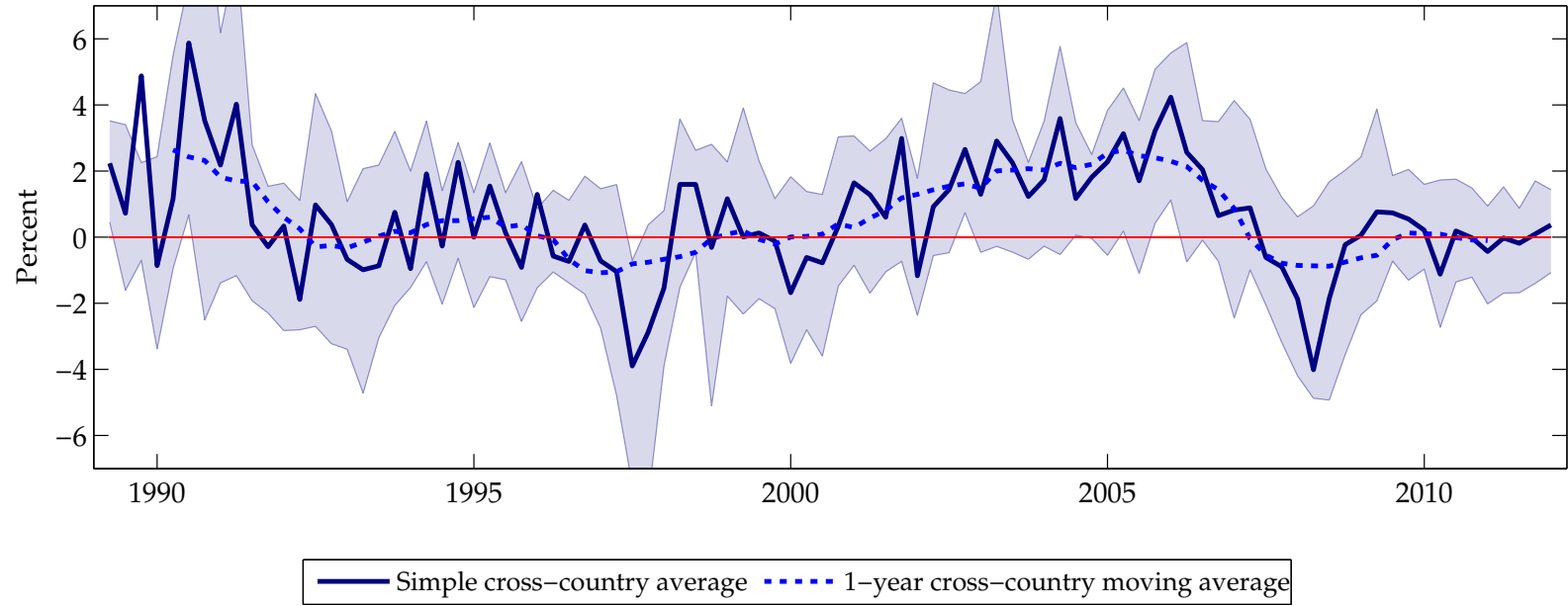

Figure 2 REAL House PRICE INFLATION. The solid lines are cross-country averages of the quarter-onquarter growth rate of real house prices. The shaded areas represent the cross-country 25/75 interquartile range. The dashed lines are rolling 1-year moving averages.

emerging markets was preceded by a sudden tightening of US monetary policy and an international capital flows reversal which led to the Mexican "Tequila” crisis in December 1994. In contrast, a very gradual but persistent acceleration of house price inflation started in advanced economies in the mid-1990s, spreading to emerging markets in the mid-2000s, and ending only in 2005-06 with the global financial crisis. The two cycles moved in closer sync since mid-2000.

\section{Co-movement Between House Prices And The Macroeconomy}

We now turn to the co-movement between real house prices and selected macroeconomic and financial variables. We compute the cross-correlation between real house prices and other variables 
as follows:

$$
\rho_{i}=\operatorname{corr}\left(H P_{i, t}, x_{i, t \pm n}\right) \quad n=0,1, \ldots, 4,
$$

where $H P_{i, t}$ is the quarterly growth rate of house prices in country $i, x_{i, t}$ is the relevant macroeconomic or financial variable in country $i$, and $n$ is the lead or lag. We consider real GDP, real private consumption, real equity prices, the real effective exchange rate (with an increase denoting an appreciation), CPI inflation, the short-term nominal interest rate, the current account to GDP ratio, and the stock of total cross-border banking flows (all instruments to banks and non-banks). House prices and all $x_{i, t}$ variables are in log-differences, except interest rates and the current account to GDP ratio, which are in simple differences. The correlations are computed country-bycountry and then averaged within groups. The 25/75 interquartile range (shaded area) reflects the group heterogeneity. The sample period is the longest available, starting in 1990:Q1.

Figure 3 reports these statistics. Advanced economies are plotted in panel (a). Consistent with the available evidence, house prices are strongly procyclical (Igan and Loungani, 2012). The correlation with GDP is positive at all leads and lags and the strongest contemporaneously and with one lead, with a value of about 0.3 . Consumption is associated even more tightly with house prices, with a contemporaneous correlation close to 0.4 . Equity prices changes are also associated with house price increases with significant leads and lags.

A consumer price inflation decline seems to follow an increase in house price inflation increase, with a contemporaneous value of about -0.2 , perhaps capturing an association between falling inflation and house price booms in the late 1990s and early 2000s. More intuitively, house price inflation leads consumer price inflation. House price inflation also leads interest rate increases. In particular, house price inflation leads changes in the same direction in nominal short-term interest rates by three to four quarters. Of course, we cannot infer any causal relation between the evolution of house prices and short-term interest rates (and, ultimately, monetary policy) from these correlations. However, they show that house price inflation is procyclical and leads inflation and interest rate changes (the latter, with a slightly stronger coefficient) by a few quarters: a set of comovement that is consistent with a monetary policy authority reacting countercyclically to output and inflation (see Ahearne, Ammer, Doyle, Kole, and Martin, 2005, for example).

The correlation with the external sector of the economy are more stable and statistically significant, but quantitatively weaker. House price changes are linked with cross-border credit flows, current account deteriorations, and real exchange rate appreciations at all lead and lags, but with weak associations. The negative correlation between house prices and the current account balance, in particular, is consistent with the evidence previously reported in other studies (Aizenman and Jinjarak, 2009, Bernanke, 2010, Ferrero, 2012). 
(a) Advanced Economies
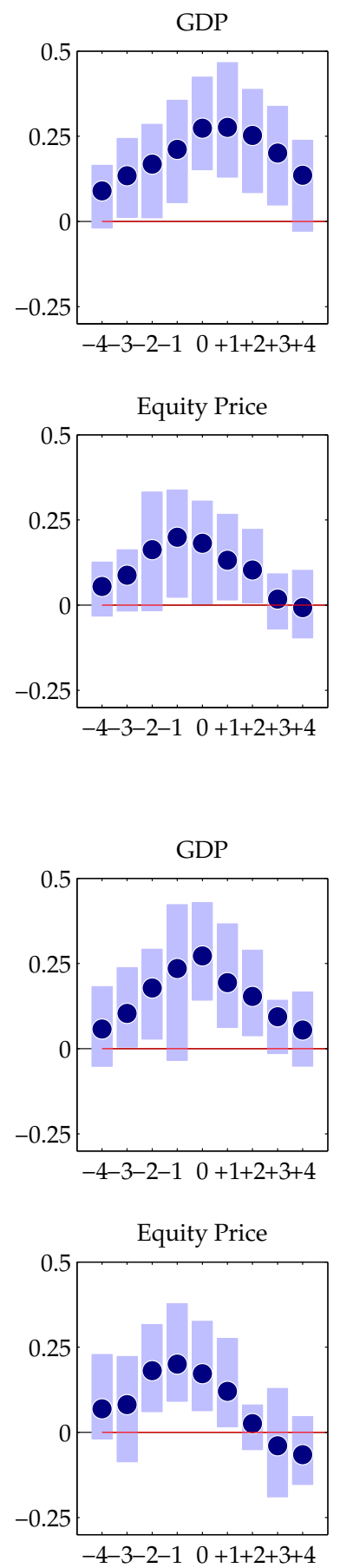

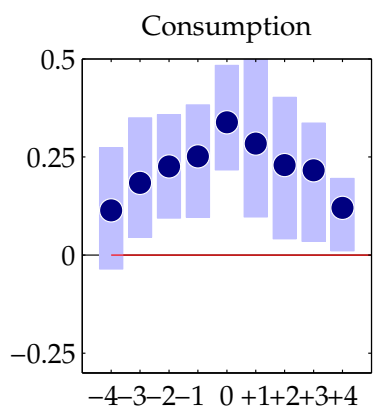

Short-term Int. Rate

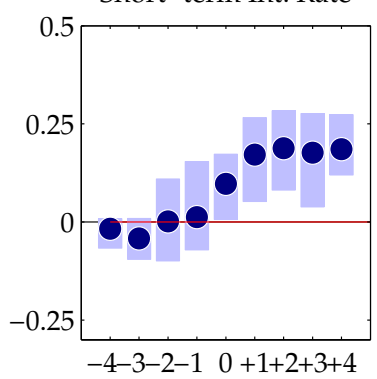

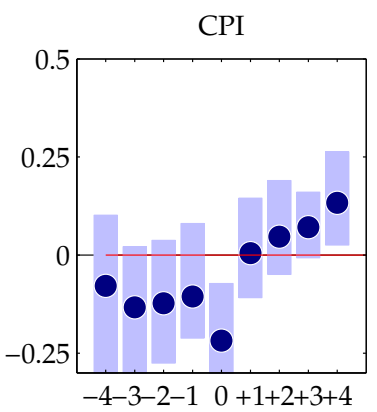

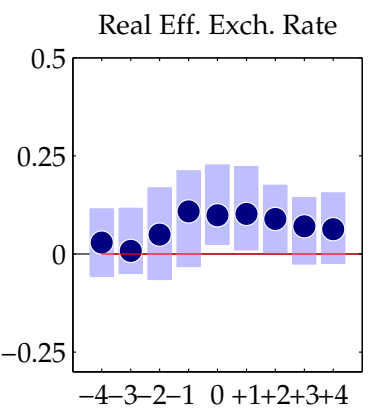

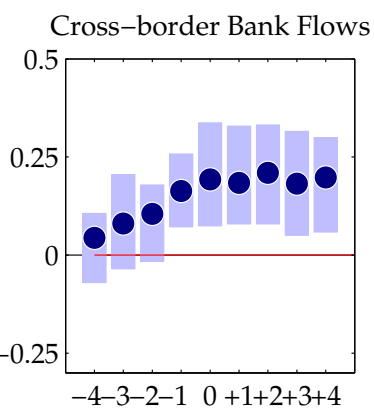

Current Account / GDP

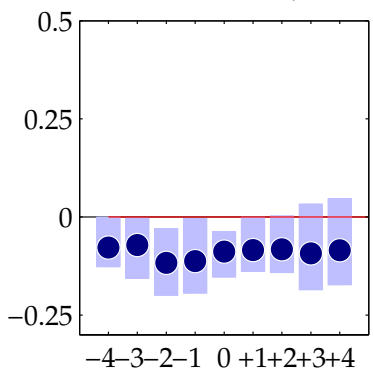

(b) Emerging Economies
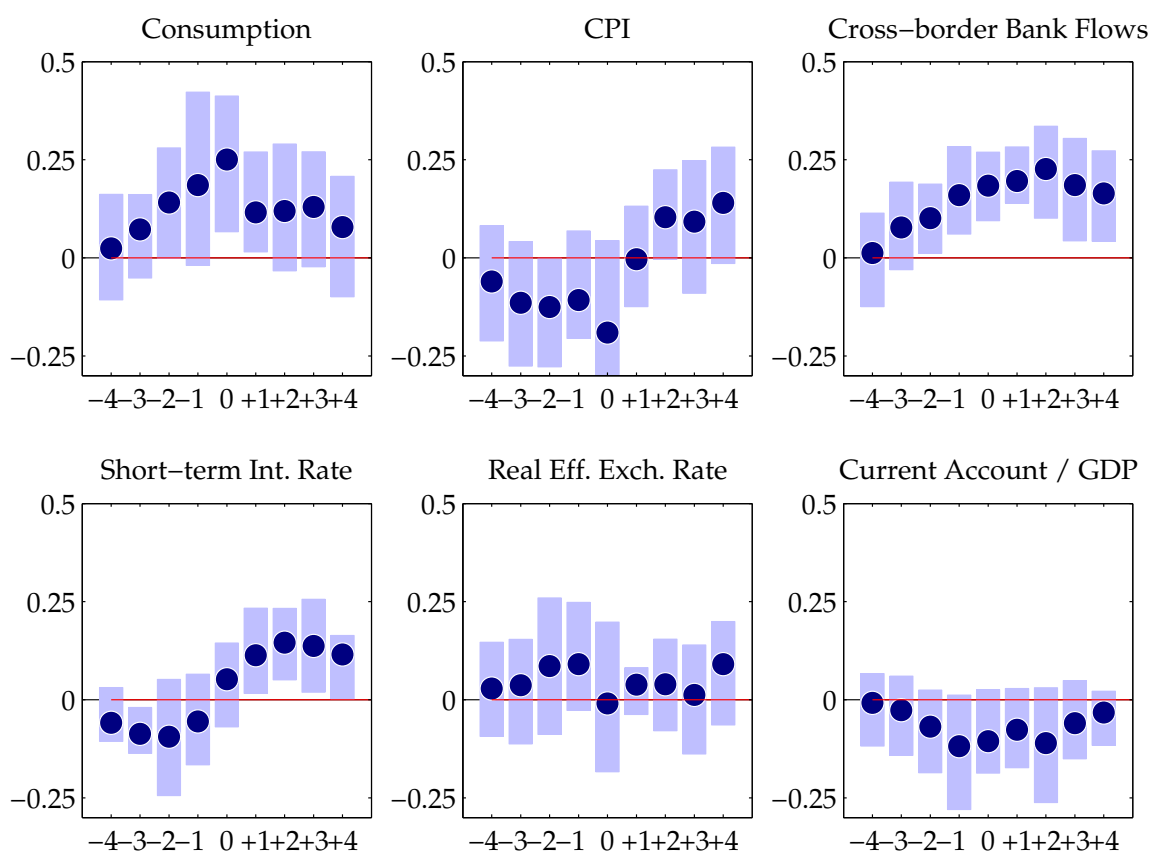

Current Account / GDP

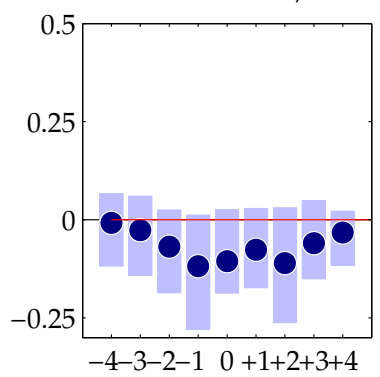

Figure 3 CROSS-CORRELATIONS. Each dot is the cross-country average of the correlation between real house price inflation and the corresponding variable at its lead or lag. The shaded areas represent the cross-country 25/75 interquartile range. All variables are in log-difference except interest rates and current account to GDP which are in simple differences. Sample period is 1990:Q1-2012:Q4. 
A similar picture emerges for emerging economies, with some important differences. Panel (b) of Figure 3 plots the same co-movements for EMs. In general, consistent with the evidence of lower persistence noted earlier, we can see that the associations in emerging economies have shorter leads and lags than in advanced economies. The link with GDP growth and equity price increases is very similar to that in advanced economies. But the link with consumption growth is weaker, especially in terms of lead coefficients. House price inflation seems to lead CPI inflation with the same timing of advanced economies. House prices also lead interest rate increases, but are followed by interest rate declines, perhaps reflecting the constraints on monetary policy originating in the external sector of the economy. Emerging markets exposed to strong capital inflows, in fact, might not be able to increase interest rates to cool their domestic economy without attracting more capital, or might have to lower them to stem exchange rate pressure.

Indeed, the connection between house price inflation and the external sector is qualitatively similar but quantitatively different in emerging markets. The association with cross-border credit and current account deteriorations, in particular, is stronger. At the same time, the association between house price inflation and real exchange rate appreciations is weaker and barely significant statistically. This suggests a stronger role for capital flows in EMs, also affecting monetary policy via its reaction to exchange rates.

Although we do not report the results, these co-movements are robust to dropping the period from 2007:Q1 to 2012:Q4 (which encompasses the global financial crisis), as well as starting the sample period in 1995 (like in the conditional analysis of the data below), or to dropping interpolated series from the analysis.

\section{Global Liquidity And Its ImPaCt ON THE MACRoeconomy}

In the next section, we will investigate the causal relation between capital flows, house prices, and the macroeconomy by focusing on a particular component of these flows: cross-border bank

lending. Cross-border bank flows are at the center of the policy and academic discussion on global funding conditions, often referred to as "global liquidity". In this section we will briefly discuss the concept of global liquidity, how it is measured, its determinants, and its transmission mechanism to house prices and the rest of the economy so as to facilitate the identification of shocks to such a variable in our empirical model and the interpretation of the estimation results.

One of the characteristics of the international economic environment that preceded the global financial crisis is the large share of bank flows in total capital flows, originated by leveraged global banks and other financial institutions (e.g., Bruno and Shin, 2015). Although their share fell after the crisis with the deleveraging of the originating institutions (Shin, 2013, Ahmed, Curcuru, 
Warnock, and Zlate, 2014), this component of international capital flows remains closely associated with debt flows and international financial conditions more generally (Rey, 2013).

On this backdrop, the BIS $(2011,2013,2014)$ and other policy institutions (see for instance a series of policy reports by the IMF) have started to monitor a board set of "global liquidity" indicators, including both price and quantity (stock and flow) measures. These indicators essentially aim at characterizing the international supply of credit, and hence financing conditions in international financial markets. The BIS banking statistics (Table 7a and 7b), in particular, permit to trace cross-border bank lending to the domestic bank sector, which is the main measure of global liquidity that we will use in our empirical analysis. ${ }^{13}$

Figure 4 plots bank-to-bank cross border lending deflated by the US CPI, both in levels and in year-on-year changes. To construct this measure we sum across all receiving countries the difference between Table 7a and Table 7b of the BIS locational statistics (BIS, 2011) and deflate it with the US CPI. According to this measure, global liquidity (GL) started to increase sharply at the beginning of the 2000s, to peak in 2007, after a long period of fluctuations around a constant level. ${ }^{14}$ After falling dramatically during the acute phase of the global financial crisis, it fluctuated around a more or less steady level, with a further decline in 2011 and 2012 in coincidence with the European crisis.

If we frame global liquidity as "international supply of credit" or "global financing conditions" it is possible to link it to house prices and the broader macroeconomy in an intuitive way. The first link in the chain involves the relationship between cross-border bank flows and their global drivers. A number of variables have been found to drive cross-border bank flows. ${ }^{15}$ These include monetary policy of the main convertible currencies, banks' willingness and ability to take on risk, as well as price and quantity measures of funding conditions.

Monetary policy indicators include the general level of interest rates and the slope of the yield curve. The latter is particularly important given the maturity transformation role of banks. Volatility in financial markets, usually proxied by the US VIX index of stock option price volatility, can

\footnotetext{
${ }^{13}$ A second concept, sometime referred to as "official global liquidity", is the sum of world international reserves (excluding gold) measured in US dollar, plus the US M0 deflated by the US CPI. This concept also captures ease of financing, but it quantifies "the funding that it is unconditionally available to settle claims through monetary authorities" (BIS, 2011) and hence it less directly impacts on house prices. As discussed by Matsumoto (2011), the concept of "private global liquidity" that we use can be seen as availability of funds for risky assets (measured by its corresponding quantity or price such as the risk premium), while "official global liquidity" is related to the availability of funds for safe assets.

${ }^{14}$ This shift coincides with the burst of the "dotcom" equity bubble and the associated monetary policy response in the United States. House price inflation in advanced economies, however, had taken off about five year earlier, in the mid-1990s (see Figure 2).

${ }^{15}$ For a discussion and an empirical analysis of their relative importance see BIS (2011) and Cerutti, Claessens, and Ratnovski (2014), respectively.
} 

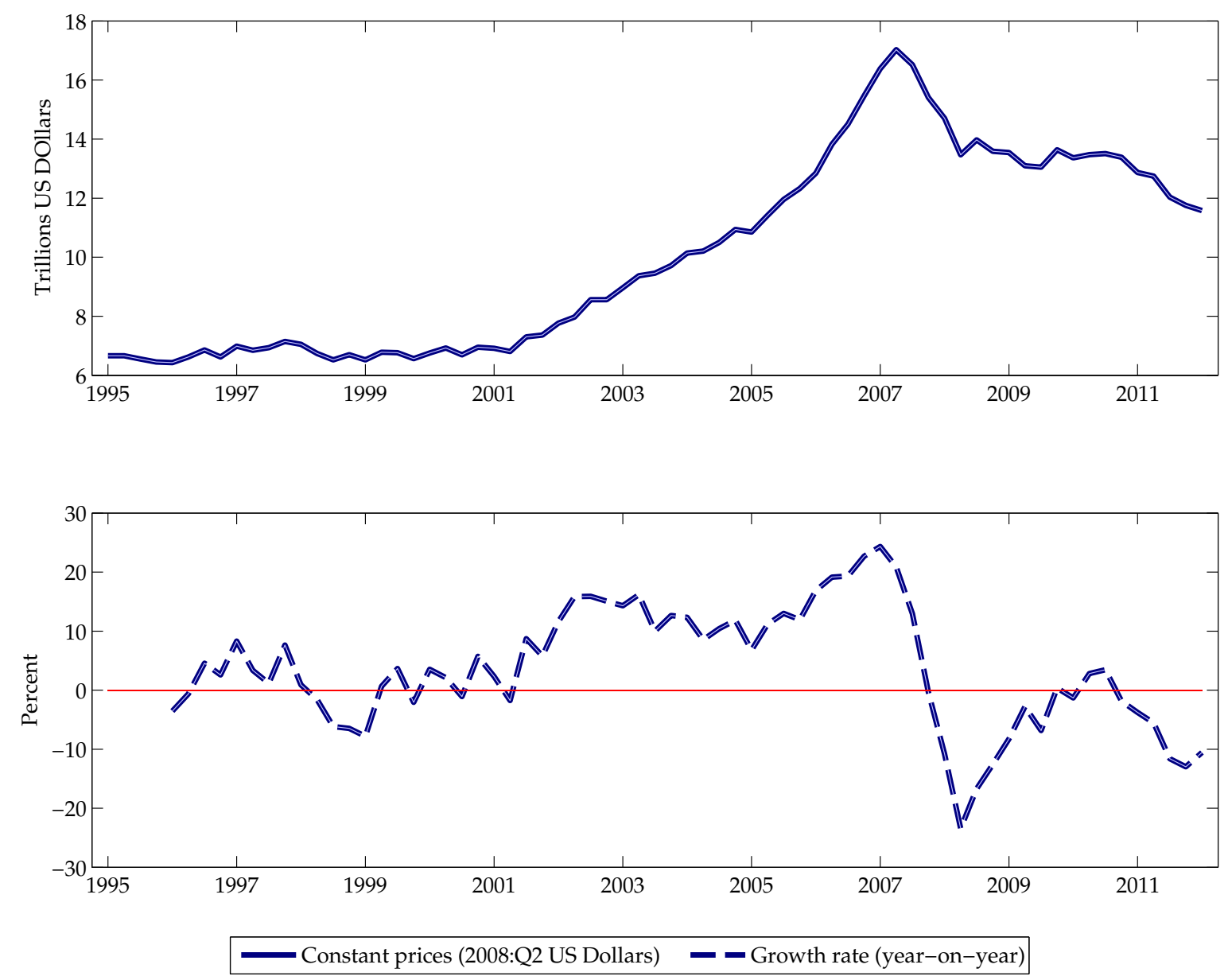

Figure 4 GLOBAL LIQUIDITY. Foreign claims (loans and deposits, in all currencies) of all BIS reporting banks vis-a-vis the banking sector deflated by US consumer price inflation, aggregated by all receiving countries. The upper panel displays the stock in constant 2008:Q2 US Dollars; the lower panel displays the year-on-year rate of growth. Source: BIS Locational banking Statistics, Tables 7A and $7 \mathrm{~B}$.

quantify banks' willingness to take on risk (see Bekaert, Hoerova, and Lo Duca, 2013). Bank leverage is perhaps the most important indicator of banks' ability to extend credit (e.g., Bruno and Shin, 2015). The TED spread (the difference between short-term interbank lending and government bond rates at same maturities) can describe the funding conditions of global banks. The literature also pointed to changes in money aggregates, such as M2, as possibly reflecting banks' access to wholesale deposits by the corporate sector. So, if we think about global liquidity as the international supply of credit, the drivers above can be thought of as vector of supply curve shifters (Cerutti, Claessens, and Ratnovski, 2014).

Next, is the link between the global credit supply and the current account. The current account balance is the excess of saving over investment, both of which are determined by households' 
and firms' resource allocation decisions. In the absence of credit constraints, these decisions are driven by real considerations, such as the real interest rate, income, and the marginal product of capital. The international supply of credit, at the margin, comes from economies with current account surpluses, while demand derives from those with deficits. An increase in the international supply of credit should therefore be associated with a swing into deficit of the receiving country's current account balance. In addition, an increase in the international supply of credit should relax any pre-existing credit constraint, domestic or international.

Another set of linkages is with the exchange rate and interest rates. With an increase in the international supply of credit, one should in principle observe a fall in the price of these funds. In practice, while the exchange rate should appreciate in response to an increase in capital inflows, short-term interest rates might go in different directions. If market forces dominate, interest rates might fall in response to an increase in the supply of capital, possibly also reflecting lower default and credit risk. Interest rates could also fall if the central bank reacts to an exchange rate appreciation by loosening the monetary policy stance accordingly, the more so the stronger the commitment to the exchange rate and the degree of international capital mobility. However, if the central bank were to react to the increased level of economic activity and inflation triggered by the capital inflow by tightening its stance, interest rates could also increase. As a result, the re-

sponse of short-term interest rates to a capital inflow shock will depend on which of these effects dominates.

The last link in the chain is between the international supply of credit and house prices. Abstracting from tax considerations and credit constraints, house prices depend on interest rates, priceto-rent ratios, and expected appreciation. Global liquidity can affect house prices via all these channels, lowering interest rates, inducing expected appreciation, and pushing up rents due to increased overall level of economic activity. In addition, a global liquidity shock may relax credit constraints directly or indirectly by increasing the value of collateral for domestic and international lending, enabling previously constrained households and financial intermediaries to increase their effective demand for housing. Note here that both house prices and the exchange rate can affect the value of collateral and therefore amplify an initial shock via the relaxation of a credit constraint.

\section{Global Liquidity, House Prices And Consumption Dynamics}

In Sections III and IV we provided evidence that the unconditional volatility of real house price inflation and the correlation between house prices and capital flows is stronger in emerging markets than in advanced economies. In this section, we will condition the analysis on a particular 
shock to capital flows. To investigate the causal link from capital flows to house prices and the broader macroeconomy, we specify and estimate a panel-vector autoregression model (PVAR) that embeds both "pull" and "push" factors, as usually assumed in the capital flows literature (e.g., Calvo, Leiderman, and Reinhart, 1996). Next we identify a shock to a particular push factor, i.e. a shock to global liquidity defined as a shift in the international supply of credit. We then trace its impact on house prices, consumption, interest rates, the exchange rate and the current account. We now present the model that we use and then report the empirical results.

\section{A The Empirical Model}

Empirical models of international capital flows typically include "push" (i.e., external) and "pull" (i.e., domestic) drivers. They are often expressed and summarized in terms of cross-country differences: interest rate differentials, growth differentials, as well as competitiveness measures reflecting differences in productivity and costs between the home and the foreign economy.

The PVAR model that we specify includes three external variables and three domestic variables. In addition to the measure of global liquidity discussed in the previous section, the external variables that we include are the real effective exchange rate and the current account to GDP. The real effective exchange rate is a measure of relative competitiveness that reflects movements in inflation rates, production costs, as well as nominal exchange rates of all trade partners. The current account is the gap between investments and savings, and hence also reflects the differences in investment opportunities at home and abroad. Both variables are affected by other domestic and external shocks, but we do not identify other shocks separately in our analysis.

The domestic variables that we include in our PVAR model are a real (ex-post) short-term interest rate, real private consumption, and real house prices. Real private consumption is the measure of economic activity that we focus on. House prices affect activity primarily through consumption and residential investments. As we do not have data on residential investments for all the emerging economies in our sample, an alternative specification would include both consumption and GDP. To keep the size of the VAR model as small as possible, we include only consumption. For the same reason, we do not include inflation and nominal interest rate separately. Thus, the real ex-post short-term interest rate is meant to reflect the monetary policy stance. A stabilizing monetary policy response should manifests itself with a change in the real interest rate. While real house prices are the focus of our analysis, they can be thought as the relative price of durable goods in the general equilibrium models with housing of Iacoviello (2005), Monacelli (2009), and Liu, Wang, and Zha (2013).

All real variables considered enter the VAR in log-levels, except the interest rate and the current 
account to GDP, which enter in levels. Following Sims, Stock, and Watson (1990), we estimate the VAR systems in levels without explicitly modeling the possible cointegration relations among them. ${ }^{16}$ But the specification is balanced, in the sense that all series have the same expected order of integration. In addition to a constant, we include a linear and a quadratic time trend to capture any long-term tendency in real consumption and house prices, and the exponential increase in global liquidity from 2001 to 2007 (Figure 4). Nonetheless, for robustness, we also estimate a specification in first differences with a constant and a linear trend.

The model is the same for all countries to avoid introducing differences in country responses due to different specifications, and because it would be difficult to find a perfectly data-congruent specification for all country in the sample. In particular, somewhat arbitrarily, but mindful of the shorter sample period for some of the emerging economies in the sample, we include two lags of each variable in every system.

\section{Estimation}

To estimate the model, we use the mean group estimator of Pesaran and Smith (1995) and Pesaran, Smith, and Im (1996). This is because pooled estimators may be inconsistent in a dynamic panel data model with heterogeneous slope coefficient (i.e., slope coefficients that vary across countries). ${ }^{17}$ This technique involves estimating the VAR model above country-by-country, with ordinary least squares, and then taking simple averages of the impulse responses across countries. One could also compute weighted averages, weighting by the inverse of the standard error of the individual estimate, or by the size of the unit in the cross-section, usually yielding similar results. Econometric theory suggests that the weights should not matter as the size of the cross-section increases (as long as no unit dominates). For reasons that we discuss below, we prefer to use equal weighting, censoring the impulse responses, rather than weighting with the size of the economy. As we will see, however, even censoring the estimates to eliminate the effects of outliers, has a negligible impact on the results.

The variance of the mean group estimator can be calculated by taking the cross-section variance of the point estimates (e.g., the variance across countries, for each time horizon, of the impulse response) and dividing it by $(N-1)$, where $N$ is the number of countries. As Pesaran and Smith (1995) and Pesaran, Smith, and Im (1996) prove, this adjustment yields a consistent estimate of

\footnotetext{
${ }^{16}$ Sims, Stock, and Watson (1990) show that if cointegration among the variables exists, the system's dynamics can be consistently estimated in a VAR in levels.

${ }^{17}$ The literature that extends this estimation approach to PVAR models is surveyed by Coakley, Fuertes, and Smith (2006) and Canova and Ciccarelli (2013). Rebucci (2010) provides Monte Carlo evidence on the performance of this estimator relative to a fixed effect estimator and a simple instrumental variable estimator.
} 
the true cross-section variance of the mean group estimate. If a country VAR has unstable roots or less than 30 observations, the country is dropped from the sample.

\section{Identification}

While the shock that we want to identify is a shift in the international supply of credit, empirically cross-border banking credit is affected by both demand and supply factors. Therefore we need a way to isolate an innovation to this variable that reflects shifts in the supply curve. In order to identify a global liquidity shock from these data, we take two steps.

First we attenuate the influence of country-specific factors by aggregating lending to all receiving countries in our sample like in Figure 4. As long as countries are not too large, innovations to these variables should not be contaminated by domestic shocks. Given this assumption, a global liquidity shock and associated impulse responses of all the other variables in the system can then be derived easily from the Cholesky decomposition of the variance covariance matrix of the estimated reduced-form residuals of each country-specific VAR, with global liquidity ordered first in the system. Note that this is equivalent to assuming that all the variation in the reduced-form residuals of the global liquidity equation are driven by external supply factors.

Second, to rule out that demand factors common among all countries in the sample, or that any particular country affects the aggregate measure, we also use the external instruments identification approach proposed by Stock and Watson (2012) and Mertens and Ravn (2013). ${ }^{18}$ This identification strategy (whose details are reported in Appendix C) uses standard instrumental variable techniques to isolate the variation of the VAR reduced-form residuals that are due to the structural shock of interest. In this way it is possible to identify the contemporaneous response of all endogenous variables in the VAR system to the shock of interest. To obtain the impulse responses at longer horizons, one can then simply simulate the VAR system forward as many steps as needed. Consistent with the empirical literature on global liquidity discussed before, the candidate instruments that we consider are the US effective federal funds rate, the log difference of US M2, the log-level and the log-difference of US broker-dealers' leverage, the slope of the US yield curve, the log-level and the log difference of the VIX, and the TED spread. ${ }^{19}$ The specific instruments used are then selected with a simple procedure that chooses the combination of variables (among all the possible combinations) that gives the highest F-Statistic in the first-stage regression. Focusing on global liquidity, therefore, allows us to specify a small VAR that embeds information

\footnotetext{
${ }^{18}$ For recent applications of this identification strategy see also Gertler and Karadi (2015).

${ }^{19}$ We enter leverage both in log-levels and log-differences following Bruno and Shin (2015). In the case of the VIX index, we found that entering both levels and first difference improves the performance of the first stage regressions.
} 
on a wider set of global factors affecting the international financing conditions, which is an important modeling consideration.

Given that our set of instruments is made up of US variables, it is hard to isolate the "foreign" component of the shock to the US system. One possibility would be to take the residual rather than the fitted value of the first stage regression for this country. This should isolate, albeit crudely, the portion of the reduced-form residual of the global liquidity equation in the US VAR system that is orthogonal to the US drivers of global liquidity (i.e., movements in global bank-to-bank cross-border flows "pushed" by non-US conditions). However, recognizing that this is a rough way to treat the problem in the case of the US, we opt for excluding the US from the PVAR for the computation of the mean group estimate. ${ }^{20}$

\section{B Estimation Results}

The model is first estimated separately for all countries for which we have more than 30 observations, using quarterly data for the period 1995:Q4 to 2012:Q4. The choice of the starting date stems from the availability of the bank-to-bank data that we use to construct our global liquidity measure, which starts in 1995. Morocco and Serbia have very short house price series and current account to GDP series, respectively, and need to be dropped from the conditional analysis, leaving us with 31 emerging economies in the sample.

We then check the stability of the system and drop countries that display unstable dynamics. The countries dropped after this second step are Austria, Brazil, and Japan. This leaves us with 30 EMs and 21 AEs in the sample.

Equipped with the reduced-form residuals from the OLS estimation of the VAR system countryby-country, we can run the first stage regressions described by equation (C.6) in Appendix C. Table 2 summarizes the results. The $R^{2}$ of these regressions are relatively low, but the F-statistics are reasonably high, especially taking into account that the procedure is applied to a large set of countries, averaging 0.05 and 3.7 for advanced economies and 0.06 and 3.7 for emerging economies, respectively. ${ }^{21}$ The coefficients of these regressions are not reported, but generally have the expected sign.

\footnotetext{
${ }^{20}$ Results including the US are very similar and available from the authors on request.

${ }^{21}$ Note that the $R^{2}$ are well below 0.1 also in the regressions of (see Cerutti, Claessens, and Ratnovski, 2014), who model this variable with a much larger set of co-variates.
} 
Table 2 Instrumental VARiable Estimation - First-Stage Statistics

(a) Advanced Economies

\begin{tabular}{lrrlrr}
\hline \hline & R2 & F-Statistic & & R2 & F-Statistic \\
\hline Australia & 0.06 & 5.10 & Japan & - & - \\
Austria & - & - & Luxembourg & 0.01 & 1.52 \\
Belgium & 0.03 & 3.14 & Malta & 0.02 & 2.42 \\
Canada & 0.05 & 2.59 & Netherlands & 0.02 & 2.41 \\
Denmark & 0.02 & 2.38 & New Zealand & 0.01 & 1.60 \\
Finland & 0.02 & 2.36 & Norway & 0.13 & 10.66 \\
France & 0.06 & 2.98 & Portugal & 0.06 & 4.94 \\
Germany & 0.06 & 5.02 & Spain & 0.04 & 3.44 \\
Greece & 0.05 & 4.56 & Sweden & 0.05 & 4.45 \\
Iceland & 0.18 & 4.53 & Switzerland & 0.05 & 2.66 \\
Ireland & 0.05 & 4.78 & United Kingdom & 0.05 & 4.67 \\
Italy & 0.02 & 2.66 & United States & - & - \\
\hline \hline
\end{tabular}

(b) Emerging Markets

\begin{tabular}{lrrlrr}
\hline \hline & R2 & F-Statistic & & R2 & F-Statistic \\
\hline Argentina & 0.06 & 5.37 & Malaysia & 0.14 & 9.43 \\
Brazil & - & - & Mexico & 0.11 & 2.80 \\
Bulgaria & 0.06 & 5.51 & Morocco & - & - \\
Chile & 0.03 & 3.19 & Peru & 0.02 & 1.90 \\
China & 0.00 & 1.17 & Philippines & 0.05 & 4.61 \\
Colombia & 0.08 & 6.97 & Poland & 0.11 & 3.78 \\
Croatia & 0.02 & 2.34 & Russia & 0.14 & 8.16 \\
Czech Republic & 0.06 & 4.44 & Serbia & - & - \\
Estonia & 0.04 & 3.35 & Singapore & 0.01 & 1.17 \\
Hong Kong & 0.05 & 4.35 & Slovakia & 0.04 & 1.35 \\
Hungary & 0.03 & 2.72 & Slovenia & 0.05 & 4.55 \\
India & 0.02 & 1.87 & South Africa & 0.01 & 1.95 \\
Indonesia & 0.06 & 4.99 & Taiwan & 0.03 & 2.67 \\
Israel & 0.06 & 2.08 & Thailand & 0.02 & 1.57 \\
Korea & 0.08 & 6.64 & Ukraine & 0.04 & 2.96 \\
Latvia & 0.03 & 2.55 & Uruguay & 0.12 & 2.89 \\
Lithuania & 0.10 & 4.01 & & & \\
\hline \hline
\end{tabular}

Note. Selected results from the first stage regression as in equation (C.6) in the appendix. For each country we report the $R^{2}$ of the regression and the F-Statistics associated with the null hypothesis that all estimated coefficients are equal to zero. 
We are now ready to discuss the impulse response functions to our global liquidity shock. We first look at impulse responses in which the shock is identified only with the first step discussed above, i.e. the Cholesky decomposition of the reduced-form residuals with global liquidity ordered first. We use a simple average of the country-specific estimates to construct the mean group estimates. We also censor the responses included in this average at the 10 percent level (5 percent each side) to eliminate the possible influence of any outlier on the averages.

Figure 5 reports these results for the typical (i.e., average) advanced and emerging economy see panel (a) and panel (b), respectively. The dark and light shaded areas represent the 1 and 2 standard deviations confidence intervals, respectively. The dashed line is the uncensored impulse response function. In the typical advanced economy (panel (a) of Figure 5), both real consumption and house prices increase in response to the global liquidity shock in a statistically significant manner, but the effect is relatively short-lived, losing statistical significance within 5-6 quarters. Specifically, consumption and house prices peak at $0.06 \%$ and about $0.1 \%$ above their long-term levels within two-three quarters. The response of the short-term real interest rate is initially mute. It then increases slowly but steadily for 3-4 quarters tracking consumption and house prices, peaking at about 4 basis points above its long-term level. This is consistent with a monetary policy authority reacting to the acceleration of economic activity triggered by the capital inflows. But it could also reflect reverse causation from domestic monetary policy to capital inflows not adequately addressed by the first step of our identification strategy. The real effective exchange appreciates on impact, arguably driven by the nominal exchange rate, peaking at about $0.2 \%$ above its long-term level, and then reverts to its equilibrium level over time. The current account displays a delayed but persistent decline, with a deficit close to $0.05 \%$ of GDP at the trough of the response.

The response of the typical emerging market economy to the same shock is qualitatively and quantitatively different (panel (b) of Figure 5). The peak responses of house prices and consumption are much stronger in emerging economies, about twice as large as in advanced economies. The interest rate response is initially negative, possibly reflecting the impact of the increased supply of credit or the desire of the monetary authority to avoid making the domestic currency even more attractive to foreign investors. It then increases gradually to the same level reached in advanced economies, reverting to its long-term level much more slowly. The exchange rate response is mute on impact, consistent with the lower degree of flexibility of the nominal exchange rate in this group of countries. But then it appreciates over time, peaking only slightly below its level in advanced economies. The current account balance displays a different boom-bust response. It first swings into a deficit twice as large as in advanced economies, and then reverts sharply into a sizable surplus. 
(a) Advanced Economies
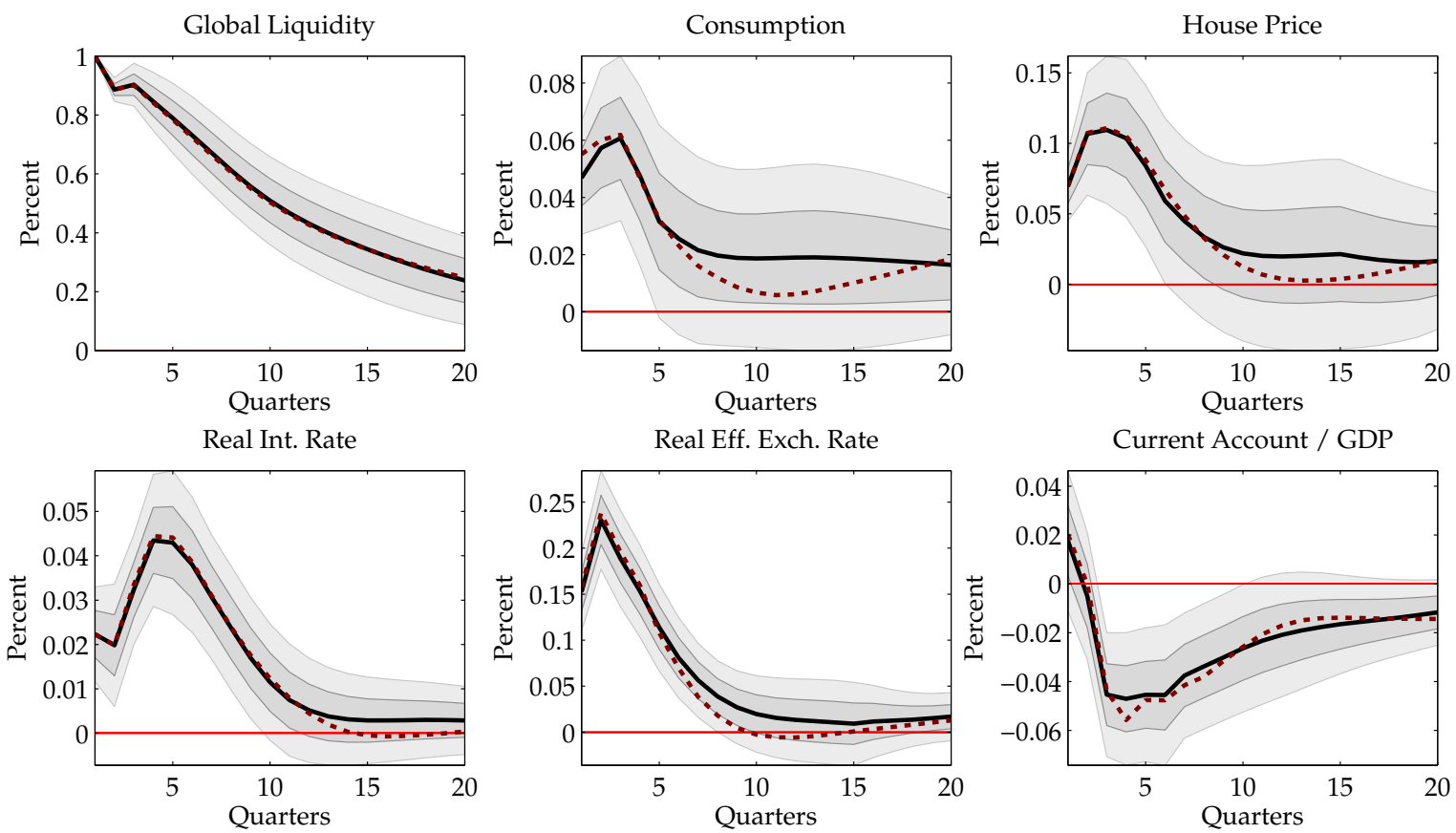

(b) Emerging Economies
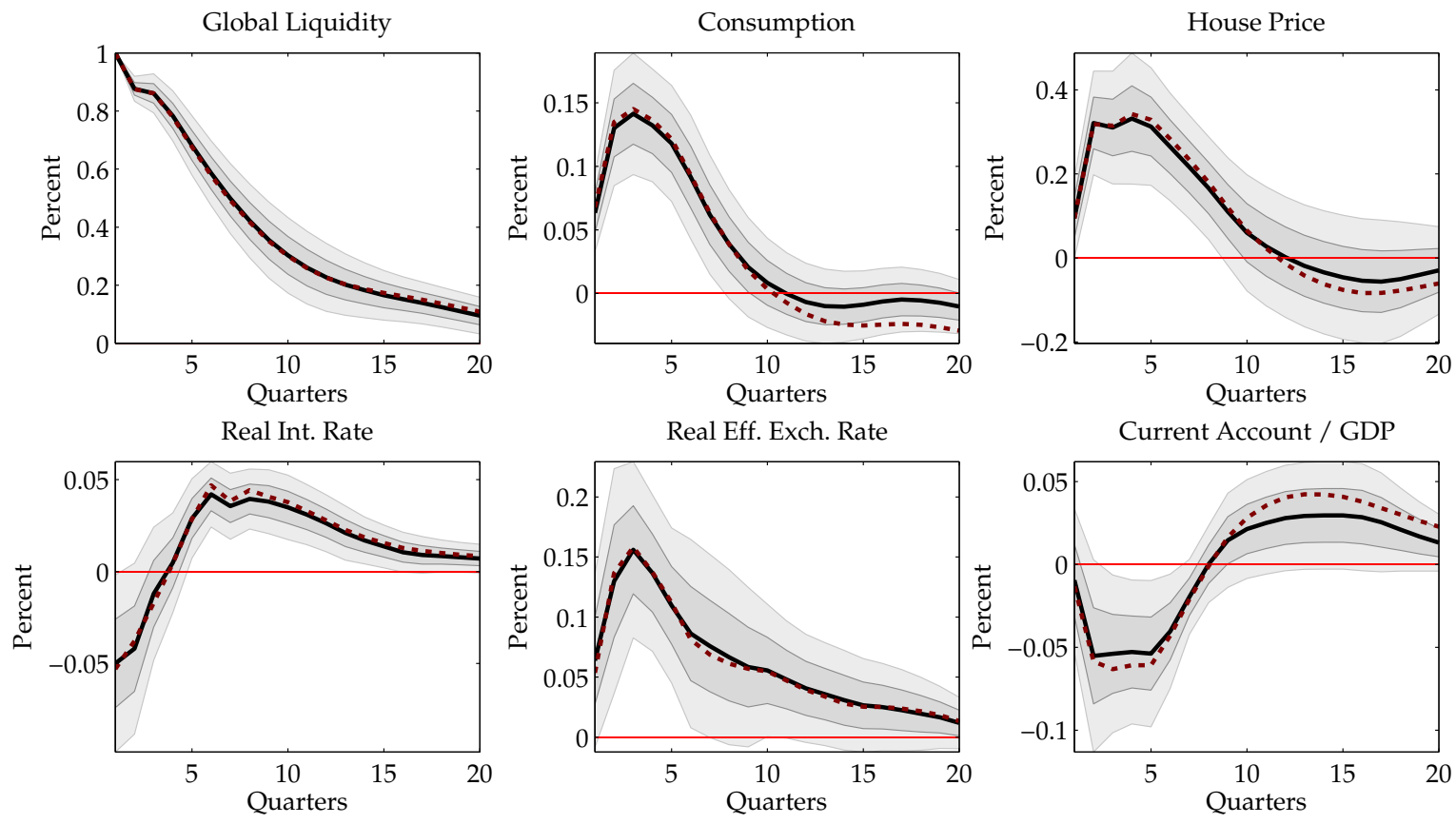

Figure 5 Global Liquidity Shock - Cholesky Identification. Censored impulse responses to a one percent shock to global liquidity in advanced and emerging economies, panel (a) and panel (b) respectively. The dark and light shaded areas are the one and two standard deviation confidence intervals. The dashed line reports the uncensored impulse responses. 
By assuming that the reduced-form residual of the global liquidity equation is entirely driven by international supply factors, the Cholesky identification might distort its estimated effects. When we refine the identification strategy by instrumenting the residual of the global liquidity equation, we actually find remarkably similar impacts and, in a few cases, even stronger effects (panel (a) and (b) of Figure 6). The estimated impact of the shock on consumption in Figure 6, in particular, is twice as large than in Figure 5, in both advanced and emerging economies. Other variables' responses are also now slightly stronger in advanced economies. In emerging economies, the interest response becomes even more negative and less precisely estimated reflecting the heterogeneity in the country sample. The current account swing into deficit is now much larger than in advanced economies. Similarly, emerging economies' house price response is now 3 times larger than in advanced economies. These results are intuitive, as advanced economies are those for which domestic pull factors might invalidate the use of the Cholesky decomposition for the identification of our global liquidity shock.

To help appreciate the economic significance of these elasticities, note that a one percent increase in our global liquidity measure corresponds to an expansion in bank-to-bank real cross border lending of about US $\$ 115$ billions after the global crisis (at constant 2008 prices), or approximately $0.15 \%$ of 2012 world GDP (at constant 2008 prices). Figure 6 suggests that an expansion of cross border credit of about $1 \%$ of world GDP can push up house prices by slightly less than $1 \%$ in AEs and more than 3\% EMs. In emerging markets, consumption increases by about $1.5 \%$, while the current account deteriorates to more than $1 \%$ of domestic GDP. We conclude from this back of the envelope calculation that the implied elasticities are economically sizable.

A battery of checks suggests that these estimation results are robust in several respects (results are reported in the extended appendix). In fact, we obtain similar results when we estimate the model in first differences, although without hump shaped responses. When we use the bilateral real exchange vis-a-vis the US dollar (instead of the real effective exchange rate), the response of the interest rate and the current account are somewhat different but overall they are consistent with the baseline results. The results are very similar when we use total cross-border banking flows (i.e., all instruments) to both banks and non-banks as an alternative measure of global liquidity. Finally, we find similar results also when we use disaggregated (i.e., country-specific) bank-to-bank cross border credit with both steps of the identification strategy outlined above. With the country-specific measure of global liquidity, however the precision of the estimates decreases, and some portions of the impulse response functions are more noisy and less clearly interpretable, but again the main results on consumption and house prices are preserved. 
(a) Advanced Economies
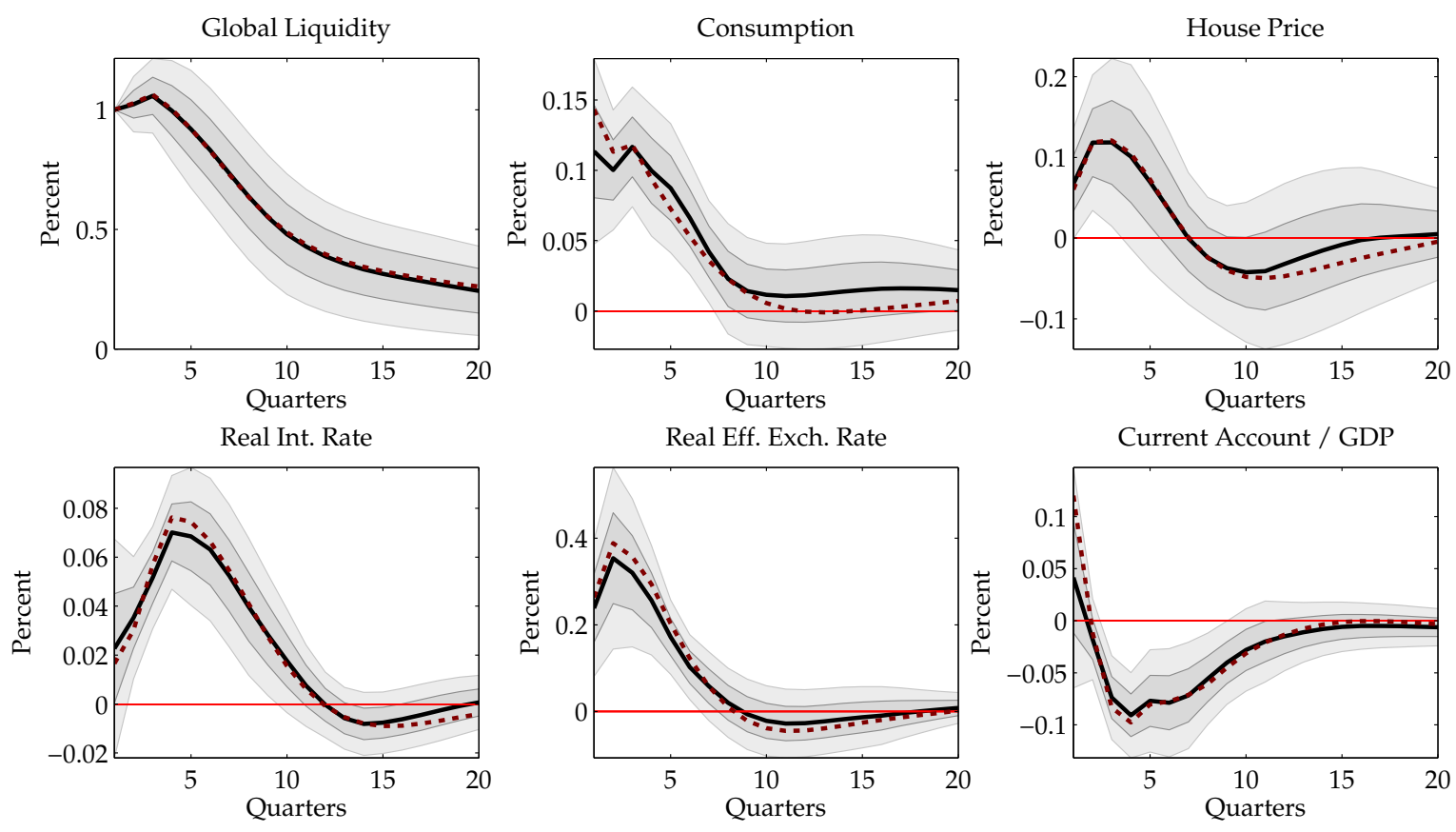

(b) Emerging Economies
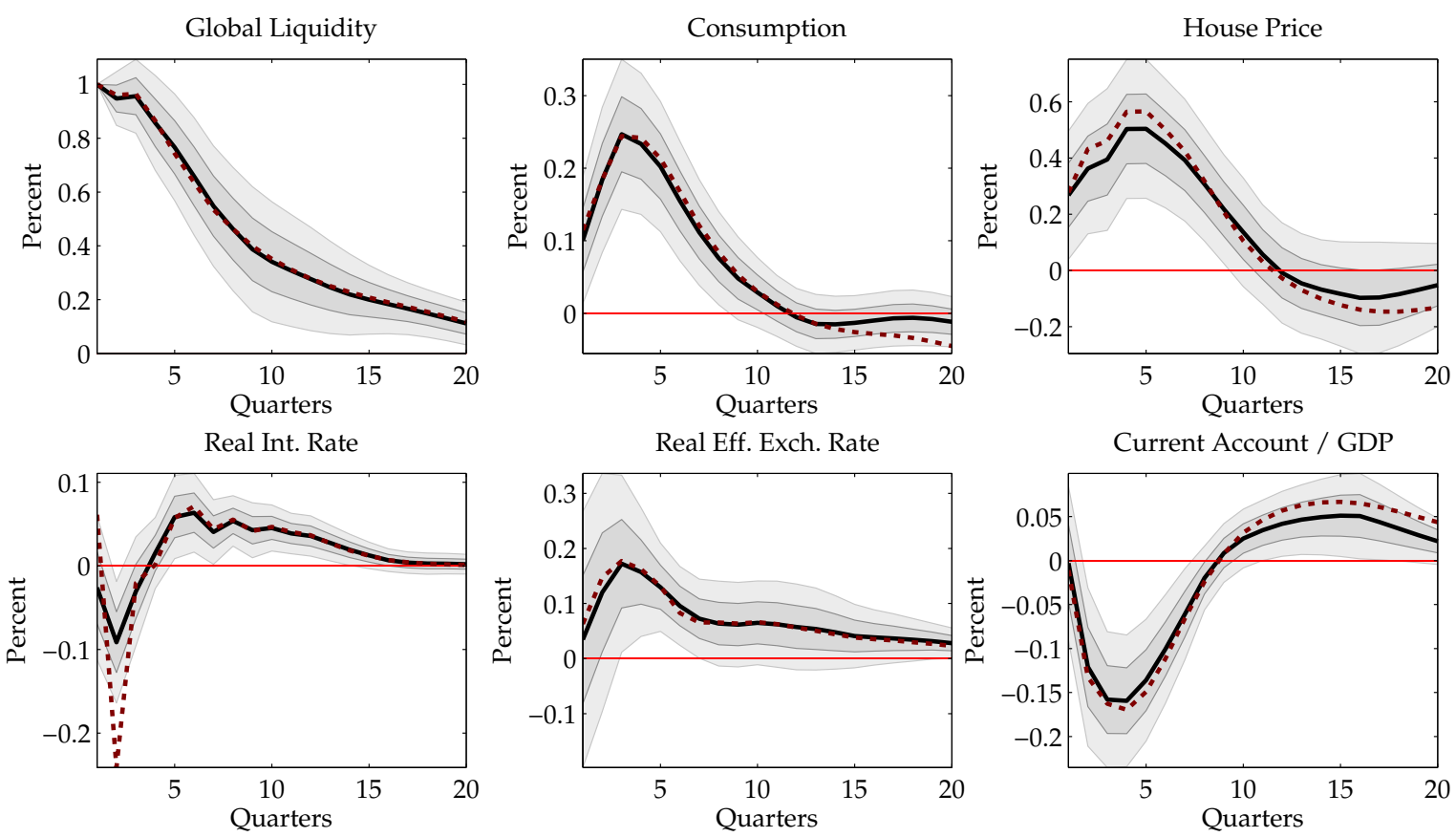

Figure 6 Global Liquidity Shock - IV IDEnTIFiCATION. Censored impulse responses to a one percent shock to global liquidity in advanced and emerging economies, panel (a) and panel (b) respectively. The dark and light shaded areas are the one and two standard deviation confidence intervals. The dashed line reports the uncensored impulse responses. 


\section{Inspecting The Transmission Mechanism}

The evidence we reported in the previous sections shows that the unconditional correlation between capital flows and house prices is stronger in emerging markets than in advanced economies. Moreover, once we condition on a particular source of exogenous capital flow variation, consumption also becomes much more responsive to capital flows in emerging markets, consistent with the much higher volatility of both house prices and consumption in this group of countries. It is therefore natural to look for possible explanations or interpretations of these facts within our empirical framework.

One possibility is to check whether financial frictions, which should be expected to be tighter in emerging economies, play a different role in the two groups of economies. A crude, yet intuitive way to investigate the impact of financial frictions in our model involves closing the channel of transmission associated with them, and then looking at the counterfactual estimated responses of the same shock.

In models with borrowing constraints, the relative price of collateral is a source of amplification of regular business cycle shocks. In our empirical model there are two asset prices: house prices and the exchange rate. Both prices can be linked to frictions either in domestic or international financial contracting. ${ }^{22}$ So we can compare baseline impulse responses to the global liquidity shock with counterfactual ones in which either the house price or the exchange rate is kept at its unconditional mean value. The difference in the two sets of responses can provide some evidence on the amplification role of these asset prices via collateral constraints.

We compute the counterfactual impulse responses using the external instruments identification strategy. ${ }^{23}$ Figure 7 plots the impulse responses when we close the house price channel. Figure 8 plots the impulse responses when we close the exchange rate channel. When we shut down the house price channel in advanced economies we have a slightly less persistent shock, accompanied by a faster reversal of consumption and the short-term interest rate to their long-term levels (panel (a) of Figure 7). This is consistent with house prices amplifying the transmission of global liquidity shock by boosting the value of housing collateral, thereby allowing for more domestic borrowing and higher consumption. short-term interest rates may be lower because of a weaker monetary policy response in the absence of amplification. The exchange rate and the current account have slightly smoother responses, but the differences relative to the baseline estimates are very small, suggesting a more limited role for international borrowing and associated frictions.

\footnotetext{
${ }^{22}$ See, for instance, Iacoviello (2005), Monacelli (2009), Liu, Wang, and Zha (2013), Bruno and Shin (2015), Cespedes, Chang, and Velasco (2012), and Gabaix and Maggiori (2014).

${ }^{23}$ Counterfactuals computed with the Cholesky identification are reported in the extended appendix.
} 
(a) Advanced Economies
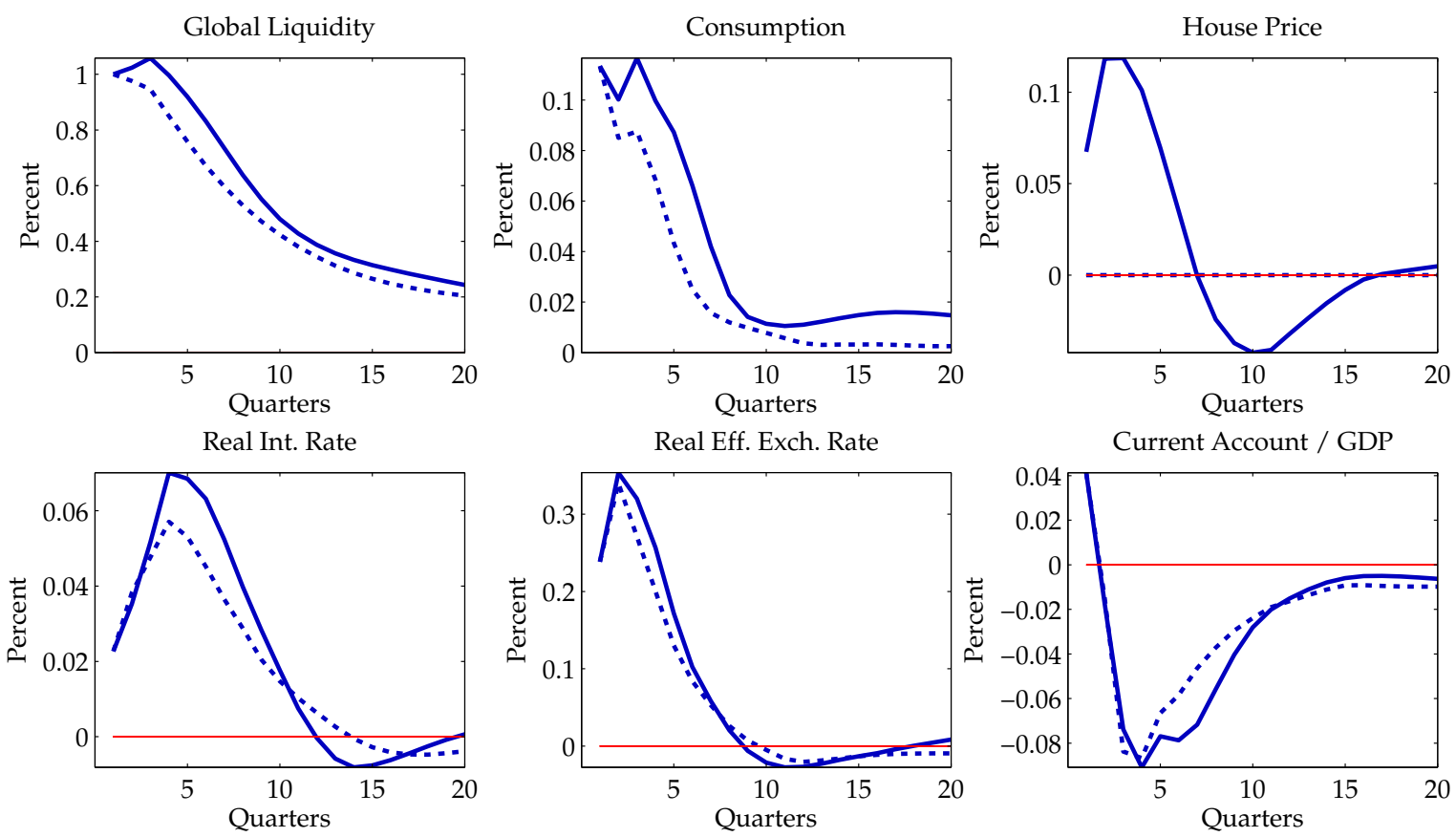

(b) Emerging Economies
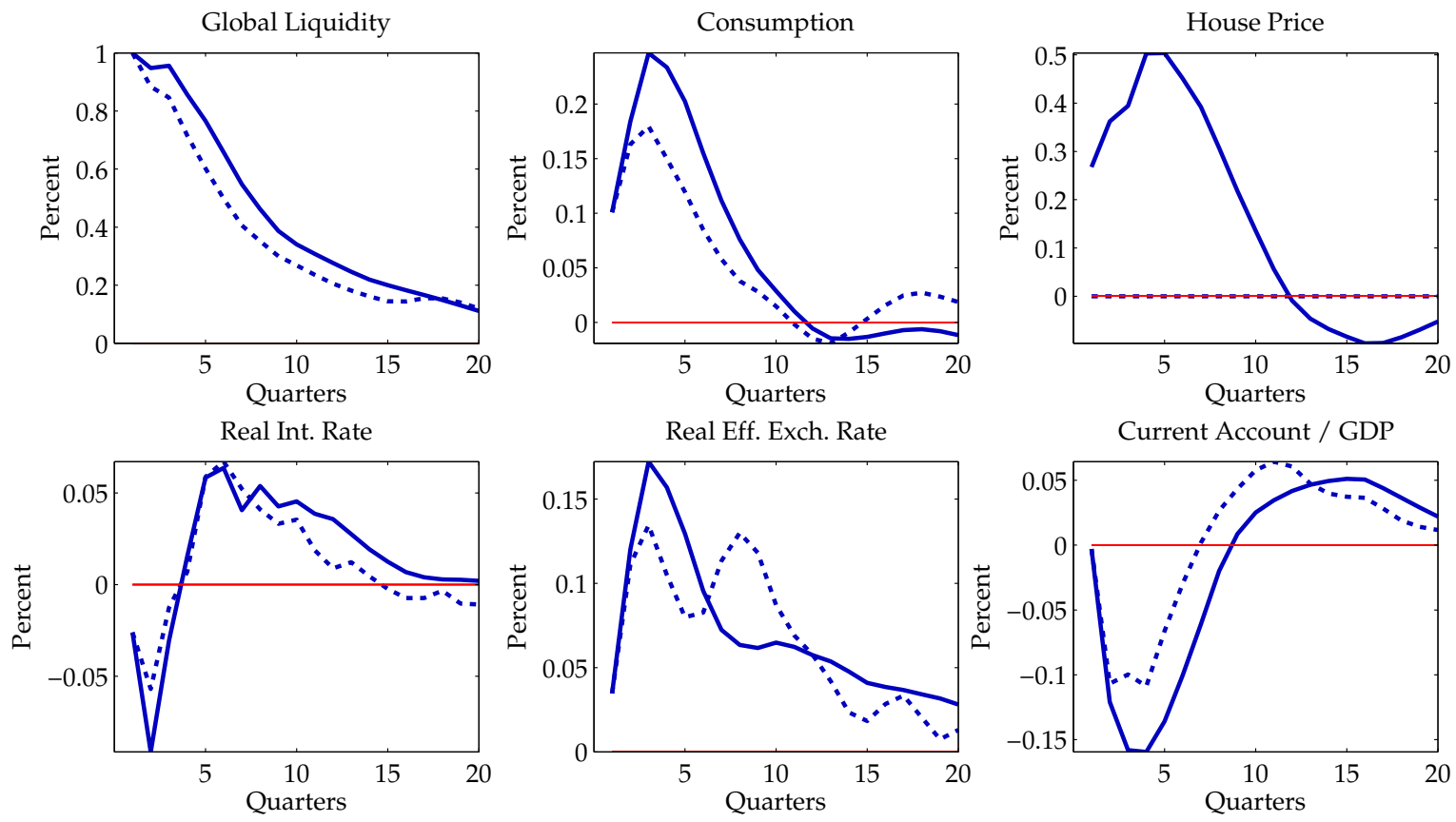

Figure 7 Global LiQuidity Shock: Housing CHANNEL - IV IDENTIFICATION. Censored impulse responses to a one percent shock to global liquidity in advanced and emerging economies, panel (a) and panel (b) respectively. Solid line is baseline; dashed line is obtained by keeping the house price at its unconditional mean value. 
In emerging economies (panel (b) of Figure 7), the dampening effect of closing the house price channel has a qualitatively similar, but quantitatively stronger impact, especially on the exchange rate and the current account. When we close the house price channel, consumption is lower during the first two years after the shock, but it is higher in the medium term. When the house price is held constant, the exchange rate and the current account display an even smoother response to the shock (with a smaller initial response and a faster reversion to long-run level in the medium term). This evidence suggests a possibly more important role for international borrowing and associated frictions in emerging markets.

When we close the house price channel in emerging economies, the response of the interest rate is marginally higher in the short-term and it is lower in the medium term. ${ }^{24}$ This is consistent with the smoother response of the rest of the system and it is different to what we see in advanced economies, where interest rates are lower when house prices are kept constant. In emerging markets, interest rates might be higher because of higher default risk when we keep the price of collateral constant. But our empirical model is not granular enough to allow us to evaluate this conjecture.

When we shut down the exchange rate channel we find other interesting differences between advanced and emerging economies. In advanced economies (panel (a) of Figure 8), the exchange rate seems to play a stabilizing role. Indeed, when we shut down the exchange rate channel, the consumption response is slightly higher, interest rates are higher, and house price bottom out at lower levels in advanced economies. This is consistent with a traditional expenditure-switching role of the exchange rate that helps absorbing the external global liquidity shock.

In contrast, in emerging economies (panel (a) of Figure 8), turning off the exchange rate channel dampens significantly the response of house prices and interest rates, and to a lesser extent also that of consumption and the current account. This evidence is consistent with the exchange rate appreciation relaxing the international borrowing capacity of the economy in response to the increased availability of external funding, contributing only indirectly to house price increases as opposed to directly (via an impact on the value of housing collateral) like in advanced economies. ${ }^{25}$

Overall, the evidence reported suggests that house prices can affect the transmission of a global liquidity shock in both groups of countries, but the mechanisms might be quite distinct. In the case of advanced economies, the main difference between the baseline and the counterfactual is the consumption response. This points to a simple housing collateral valuation effect in which

\footnotetext{
${ }^{24}$ The short-term interest response is clearly higher than in the baseline estimate when we close the house price channel and use the Cholesky identification (see Figure 9 in the extended appendix).

${ }^{25}$ Interestingly, this evidence is consistent with the findings of Cardarelli, Igan, and Rebucci (2008) and Calza, Monacelli, and Stracca (2013), who show that, within advanced economies, the more liberalized the domestic housing finance system, the stronger is the spillover from the housing sector to consumption and the rest of the economy.
} 
(a) Advanced Economies
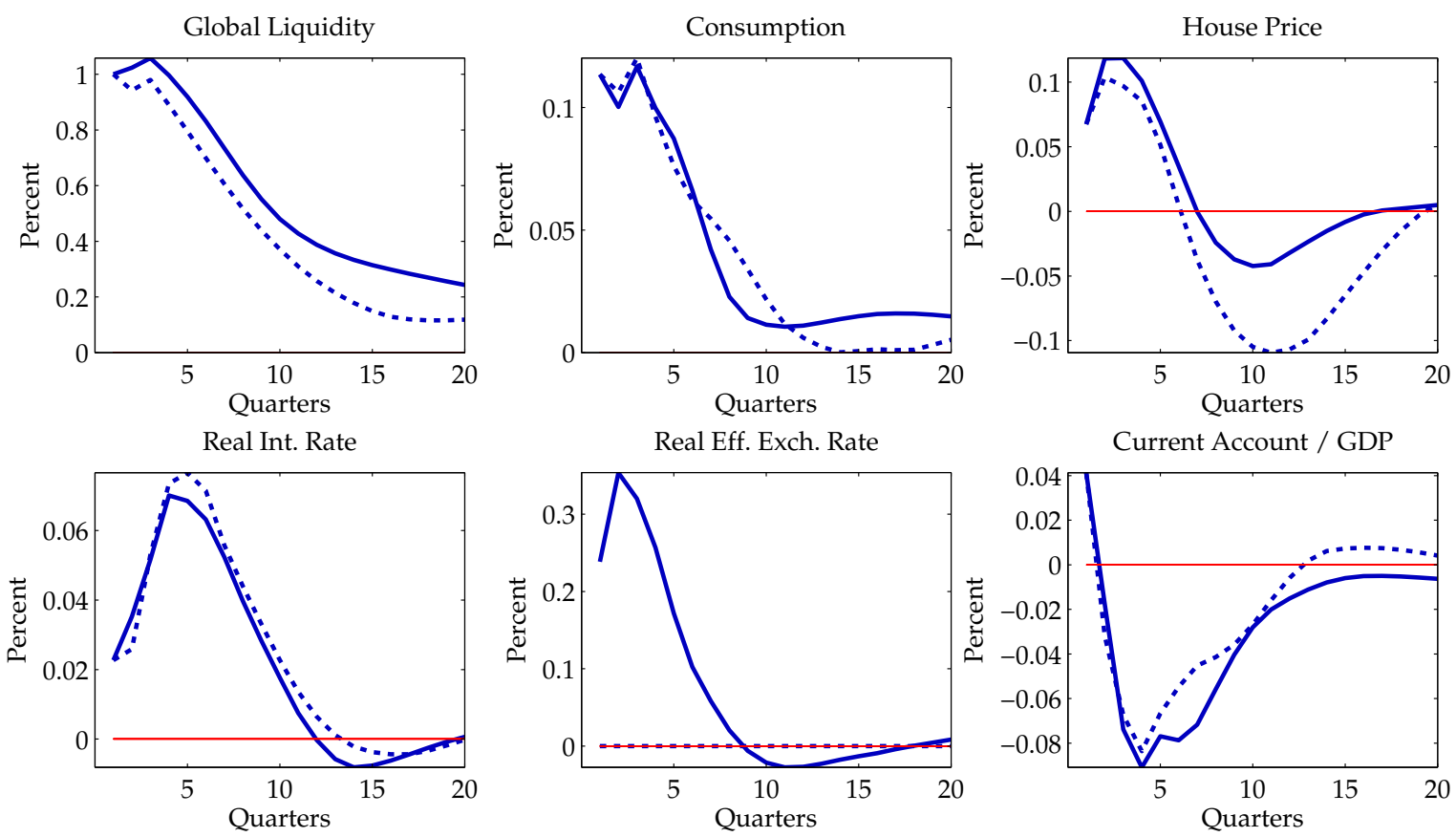

(b) Emerging Economies
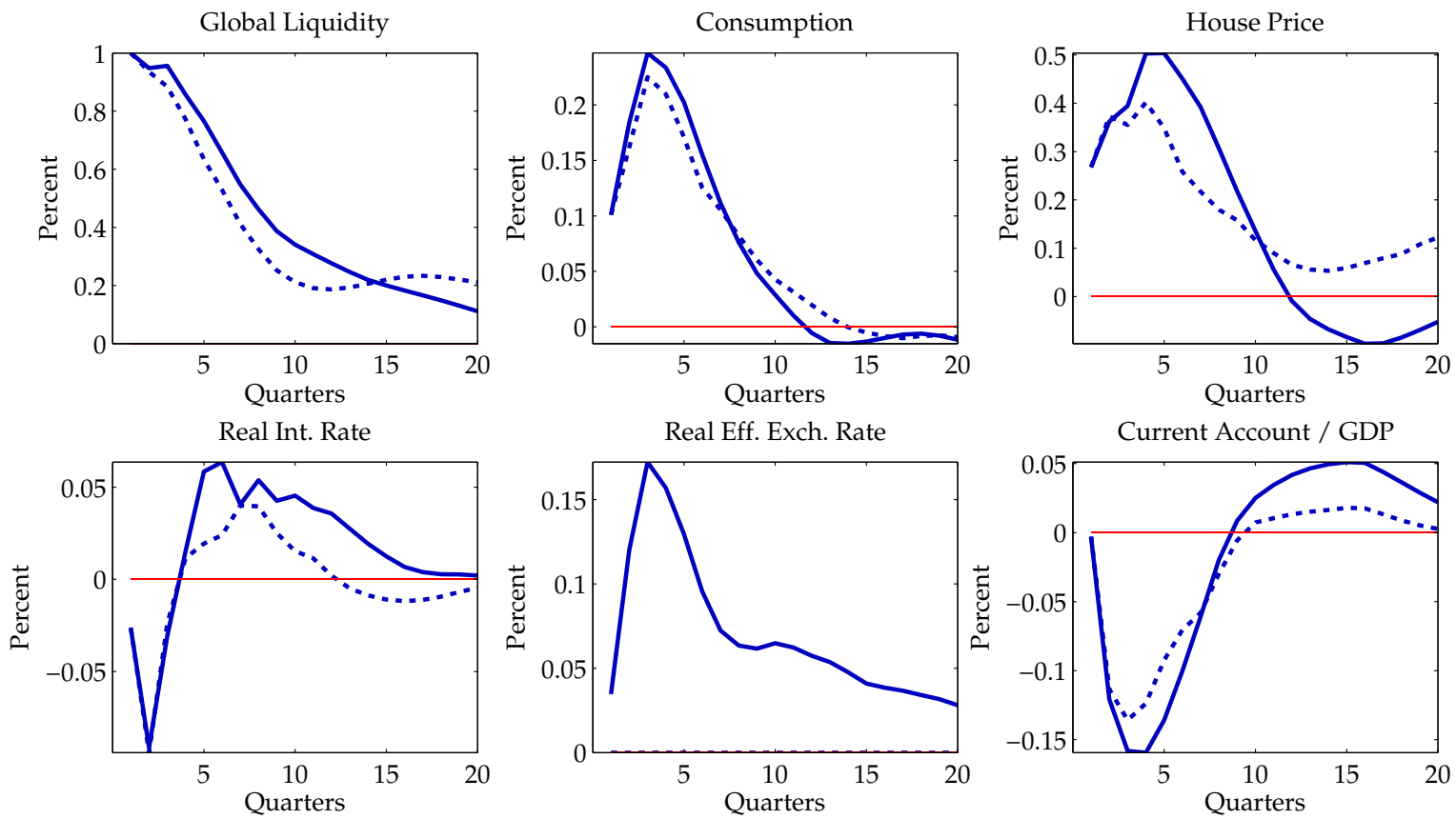

Figure 8 Global LiQuidity Shock: ExChAnge Rate CHANNEL - IV IDENTIFICATION. Censored impulse responses to a one percent shock to global liquidity in advanced and emerging economies, panel (a) and panel (b) respectively. Solid line is baseline; dashed line is obtained by keeping the exchange rate at its unconditional mean value. 
house prices can expand the borrowing capacity of households. In emerging economies, house prices possibly work more through their impact on the exchange rate (which can, in turn, feedback onto house prices). Indeed, in emerging economies, the main difference between the baseline and the counterfactual estimates when we hold house prices constant is the exchange rate and the current account response. And when we close the exchange rate channel, we find that house prices are much more stable in this group of economies.

\section{CONCLUSIONS}

In this paper, we compare the behavior of house prices over the business cycle in advanced and emerging economies based on a new house price data set for 33 emerging markets. First, we compare unconditional moments over the period 1990-2012 as well as their cross-correlations with a small set of macroeconomic and financial variables. Next, we explore the transmission of a particular shock to capital flows, namely a shock to the international supply of credit, on house prices, consumption, the real exchange rate, and the current account. We identify this shock, which we label a "global liquidity" shock, by applying the external instrumental variable approach of Stock and Watson (2012) and Mertens and Ravn (2013) in a panel VAR model for both groups of countries. Finally we close two channels of transmission possibly associated with financial frictions and explore their relative importance in the transmission of our global liquidity shock.

We find that house prices in emerging economies grow faster, are much more volatile, less persistent, and less synchronized than in advanced economies. House prices in emerging economies also seem more closely associated with capital flows than in advanced economies. When we condition the analysis on our global liquidity shock, we find that in emerging markets both consumption and house prices respond much more to this shock than in advanced economies.

We also find that house prices amplify the response to global liquidity shocks in both advanced and emerging economies, but possibly through different mechanisms. In advanced economies, arguably by boosting the value of housing collateral and hence supporting household borrowing; in emerging markets, by generating a more appreciated exchange rate (and possibly a lower default risk), which in turn feeds back onto house prices and supports the international borrowing capacity of the economy.

Indeed, we find that when we hold the exchange rate constant the cycle becomes more volatile in advanced economies, while in emerging markets it is more stable. The exchange rate seems to have a traditional shock absorbing role in advanced economies and collateral valuation effect in emerging economies. Indeed, studying the interaction between house prices and the exchange 
rate in models with both domestic and international financial friction may be an interesting area of future research. 


\section{References}

AdAm, K., P. KuAng, And A. Marcet (2012): "House Price Booms and the Current Account," NBER Macroeconomics Annual, 26(1), 77 - 122.

Ahearne, A. G., J. Ammer, B. M. Doyle, L. S. Kole, And R. F. Martin (2005): "Monetary policy and house prices: a cross-country study," International Finance Discussion Papers 841, Board of Governors of the Federal Reserve System (U.S.).

Ahmed, S., S. Curcuru, F. Warnock, And A. Zlate (2014): "Portfolio Flows to Emerging Market Economies," Unpublished manuscript.

AiZENMAN, J., AND Y. JinJARAK (2009): “Current account patterns and national real estate markets," Journal of Urban Economics, 66(2), 75-89.

Andre, C. (2010): “A Bird's Eye View of OECD Housing Markets,” OECD Economics Department Working Papers 746, OECD, Economics Department.

BeKaert, G., M. Hoerova, AND M. Lo DuCA (2013): "Risk, uncertainty and monetary policy," Journal of Monetary Economics, Elsevier, 60(7), 771-788.

Bernanke, B. S. (2010): "Monetary Policy and the Housing Bubble," Speech at the Annual Meeting of the American Economic Association, Atlanta, Georgia, January 3, 2010, available at http://www.federalreserve.gov/newsevents/speech/bernanke20100103a.htm.

BIS (2011): Global liquidity - concept, measurement and policy implications, no. 45 in CGFS Papers. Bank for International Settlements.

— (2013): "Global liquidity: selected indicators," Global liquidity indicators.

(2014): “Global liquidity: selected indicators," Global liquidity indicators.

BRuno, V., AND H. S. SHIN (2015): “Cross-Border Banking and Global Liquidity,” forthcoming in the Review of Economic Studies.

Calvo, G. A., L. Leiderman, And C. M. Reinhart (1996): "Inflows of Capital to Developing Countries in the 1990s," Journal of Economic Perspectives, 10(2), 123-139.

Calza, A., T. Monacelli, And L. StracCA (2013): "Housing Finance And Monetary Policy," Journal of the European Economic Association, 11, 101-122.

Canova, F., AND M. CicCARElli (2013): “Panel Vector Autoregressive Models: A Survey,” CEPR Discussion Papers 9380, C.E.P.R. Discussion Papers.

CARdarelli, R., D. IgAn, AND A. RebuCCI (2008): "The changing housing cycle and implications for monetary policy," in World Economic Outlook, April 2008, world economic outlook 3. Washington: International Monetary Fund.

Cerutti, E., S. Claessens, And L. Ratnovski (2014): “Global Liquidity and Drivers of Cross-Border Bank Flows,” IMF Working Papers 14/69, International Monetary Fund.

CESA-BiAnCHI, A. (2013): "Housing cycles and macroeconomic fluctuations: A global perspective," Journal of International Money and Finance, 37(C), 215-238.

Cespedes, L. F., R. Chang, And A. Velasco (2004): "Balance Sheets and Exchange Rate Policy," American Economic Review, American Economic Association, 94(4), 1183-1193. 
(2012): "Financial Intermediation, Exchange Rates, and Unconventional Policy in an Open Economy," NBER Working Papers 18431, National Bureau of Economic Research, Inc.

Claessens, S., A. Kose, L. Laeven, And F. Valencia (2013): "Understanding Financial Crises: Causes, Consequences, and Policy Responses," CEPR Discussion Papers, C.E.P.R. Discussion Papers 9310, C.E.P.R. Discussion Papers.

Claessens, S., M. A. Kose, And M. E. Terrones (2012): "How do business and financial cycles interact?," Journal of International Economics, 87(1), 178-190.

Coakley, J., A.-M. Fuertes, AND R. SMith (2006): "Unobserved heterogeneity in panel time series models," Computational Statistics \& Data Analysis, 50(9), 2361-2380.

Favilukis, J., D. Kohn, S. C. Ludvigson, AND S. V. Nieuwerburgh (2012): "International Capital Flows and House Prices: Theory and Evidence," in Housing and the Financial Crisis, NBER Chapters. National Bureau of Economic Research, Inc.

Ferrero, A. (2012): "House price booms, current account deficits, and low interest rates," Staff Reports 541, Federal Reserve Bank of New York.

ForNi, M., AND L. REICHLIN (1998): "Let's Get Real: A Factor Analytical Approach to Disaggregated Business Cycle Dynamics," Review of Economic Studies, 65(3), 453-73.

Gabaix, X., AND M. Maggiori (2014): “International Liquidity and Exchange Rate Dynamics,” NBER Working Papers 19854, National Bureau of Economic Research, Inc.

Gertler, M., AND P. KARAdi (2015): "Monetary Policy Surprises, Credit Costs and Economic Activity,” forthcoming in American Economic Journal: Macroeconomics.

GeTE, P. (2009): “Housing Markets and Current Account Dynamics," MPRA Paper 20957, University Library of Munich, Germany.

Hirata, H., M. A. Kose, C. Otrok, And M. E. Terrones (2012): "Global House Price Fluctuations: Synchronization and Determinants," in NBER International Seminar on Macroeconomics 2012, NBER Chapters. National Bureau of Economic Research, Inc.

Iacoviello, M. (2005): "House Prices, Borrowing Constraints, and Monetary Policy in the Business Cycle," American Economic Review, 95(3), 739-764.

IgAn, D., AND P. Loungani (2012): “Global Housing Cycles,” IMF Working Papers 12/217, International Monetary Fund.

Laibson, D., AND J. Mollerstrom (2010): "Capital Flows, Consumption Booms and Asset Bubbles: A Behavioural Alternative to the Savings Glut Hypothesis," Economic Journal, 120(544), 354-374.

LANDAU, J.-P. (2013): “Global Liquidity: Public and Private,” Unpublished manuscript.

LIU, Z., P. WANG, AND T. ZHA (2013): "Land ÂŘPrice Dynamics and Macroeconomic Fluctuations,” Econometrica, Econometric Society, 81(3), 1147-1184.

Matsumoto, A. (2011): "Global Liquidity: Availability of Funds for Safe and Risky Assets," IMF Working Papers 11/136, International Monetary Fund.

Mertens, K., AND M. O. RaVn (2013): “The Dynamic Effects of Personal and Corporate Income Tax Changes in the United States," American Economic Review, 103(4), 1212-47.

MonACELLI, T. (2009): "New Keynesian models, durable goods, and collateral constraints," Journal of Monetary Economics, 56(2), 242-254. 
Pesaran, M. H. (2006): "Estimation and Inference in Large Heterogeneous Panels with a Multifactor Error Structure," Econometrica, Econometric Society, 74(4), 967-1012.

Pesaran, M. H., AND R. SMith (1995): "Estimating long-run relationships from dynamic heterogeneous panels," Journal of Econometrics, 68(1), 79-113.

Pesaran, M. H., R. Smith, AND K. IM (1996): "Dynamic Linear Models for Heterogenous Panels," in The Econometrics of Panel Data, ed. by L. Mtys, and P. Sevestre, chap. 8, pp. 145-195. Kluwer Academic Publishers, Dordrecht, The Netherlands.

REBUCCI, A. (2010): "Estimating VARs with long stationary heterogeneous panels: A comparison of the fixed effect and the mean group estimators," Economic Modelling, 27(5), 1183-1198.

REY, H. (2013): "Dilemma not trilemma: the global cycle and monetary policy independence," Proceedings - Economic Policy Symposium - Jackson Hole, pp. 1-2.

SA, F., P. Towbin, AND T. Wieladek (2014): “Capital Inflows, Financial Structure And Housing Booms," Journal of the European Economic Association, 12(2), 522-546.

ShIN, H. S. (2013): “The Second Phase of Global Liquidity and Its Impact on Emerging Economies," Keynote address at the Federal Reserve Bank of San Francisco Asia Economic Policy Conference, November 3-5, 2013.

Sims, C. A., J. H. Stock, AND M. W. Watson (1990): "Inference in Linear Time Series Models with Some Unit Roots," Econometrica, 58(1), 113-44.

Stock, J., AND M. WATson (2012): “Disentangling the Channels of the 2007-2009 Recession," Brookings Papers on Economic Activity, Spring, 81-135. 


\section{A Appendix. Data Sources}

This appendix provides a description of the data used in the empirical analysis and on their sources. We consider 57 countries in our empirical analysis: 24 advanced economies (Australia, Austria, Belgium, Canada, Denmark, Finland, France, Germany, Greece, Iceland, Ireland, Italy, Japan, Luxembourg, Malta, Netherlands, New Zealand, Norway, Portugal, Spain, Sweden, Switzerland, UK, and US) and 33 emerging economies (Argentina, Brazil, Bulgaria, Chile, China, Colombia, Croatia, Czech Republic, Estonia, Hong Kong, Hungary, India, Indonesia, Israel, Korea, Latvia, Lithuania, Malaysia, Mexico, Morocco, Peru, Philippines, Poland, Russia, Serbia, Singapore, Slovakia, Slovenia, South Africa, Taiwan, Thailand, Ukraine, and Uruguay).

We collect data over the 1990:Q1 - 2012:Q4 (subject to data availability) for the following variables:

- House prices. Nominal house prices deflated by consumer price inflation. Source: OECD house price database, BIS Residential property price statistics, Dallas FED International House Price Database, National Central Banks, National Statistical Offices, academic and policy publications. More details on the definitions and the sources are reported in Table A.1.

- Total cross-border banking flows. Foreign claims (all instruments, in all currencies) of all BIS reporting banks vis-à-vis all sectors deflated by US consumer price inflation. Source: BIS.

- Global liquidity. Foreign claims (loans and deposits, in all currencies) of all BIS reporting banks vis-à-vis the banking sector deflated by US consumer price inflation. Source: BIS.

- GDP. Real index. Source: OECD, IMF IFS, Bloomberg.

- Consumption. Real private final consumption index. Source: OECD, IMF, IFS, Bloomberg.

- Consumer prices. Consumer price index. Source: OECD, IMF IFS, Bloomberg.

- Short-term interest rates. Short-term nominal market rates. A real ex-post interest rate is obtained by subtracting consumer price inflation. Source: OECD, IMF, IFS, Bloomberg.

- Equity prices. Equity price index deflated by consumer price inflation. Source: OECD, IMF IFS, Bloomberg.

- Exchange rate vis-à-vis US dollar. US dollars per unit of domestic currency. A real exchange rate is obtained with US and domestic consumer price inflation. Source: Datastream.

- Real effective exchange rate. Index (such that a decline of the index is a depreciation). Source: IMF IFS, BIS, Bloomberg.

- Current account to GDP ratio. Current account balance divided by nominal GDP. Source: OECD, IMF IFS, Bloomberg. 
Table A.1 House Price Data: Definitions And Sources

\begin{tabular}{|c|c|c|}
\hline Country & Definition & Source \\
\hline Argentina & House Apartments in Buenos Aires City, average price per sqm (US Dollars). & Arklems \\
\hline Australia & House Price Indexes: Eight Capital Cities. & OECD \\
\hline Austria & Residential property prices, new and existing dwellings. & OECD \\
\hline Belgium & Residential property prices, existing dwellings, whole country. & OECD \\
\hline Brazil & Residential Real Estate Collateral Value Index. & Central Bank \\
\hline Bulgaria & Residential property price, existing flats (big cities), per sqm. & BIS \\
\hline Canada & Average existing home prices. & OECD \\
\hline Chile & HPI general, houses and apartments. & Central Bank \\
\hline China & House price index. & OECD \\
\hline Colombia & House Price Index. & Central Bank \\
\hline Croatia & House price index & Dallas FED \\
\hline Czech Rep. & Residential property prices, existing dwellings, whole country. & OECD \\
\hline Denmark & Price index for sales of property. & OECD \\
\hline Estonia & Residential property prices, all dwellings, per sqm. & BIS \\
\hline Finland & Prices of dwellings. & OECD \\
\hline France & Indice trimestriel des prix des logements anciens. & OECD \\
\hline Germany & Residential property prices in Germany. & OECD \\
\hline Greece & Prices of dwellings. & OECD \\
\hline Hong Kong & Residential property price, all dwellings, per sqm. & BIS \\
\hline Hungary & Residential property price, all dwellings, per sqm. & BIS \\
\hline Iceland & Residential property price, all dwellings (Reykjavk), per sqm. & BIS \\
\hline India & Residex. & Nat. Hous. Bank \\
\hline Indonesia & Residential property prices, new houses (big cities), per dwelling. & BIS \\
\hline Ireland & Residential property price index. & OECD \\
\hline Israel & Prices of dwellings. & OECD \\
\hline Italy & Residential property prices, existing dwellings, whole country. & OECD \\
\hline Japan & Urban Land Price Index. & OECD \\
\hline Korea & House price index. & Dallas FED \\
\hline Latvia & Residential property prices, new and existing flats, whole country. & $\mathrm{ECB}$ \\
\hline Lithuania & Residential property price, all dwellings, per sqm. & BIS \\
\hline Luxembourg & House price index. & Dallas FED \\
\hline Malaysia & Residential property prices, all dwellings, per sqm. & BIS \\
\hline Malta & Property Prices Index (based on advertised prices). & Central Bank \\
\hline Mexico & Residential property prices, all dwellings, per dwelling. & BIS \\
\hline Morocco & Residential property prices, existing dwellings, per sqm. & BIS \\
\hline Netherlands & House Price Index for existing own homes. & OECD \\
\hline New Zealand & House price index. & OECD \\
\hline Norway & House price index. & OECD \\
\hline Peru & Residential property prices, per sqm. & BIS \\
\hline Philippines & Residential and commercial property prices, flats (Makati), per sqm. & BIS \\
\hline Poland & Residential property prices, (big cities), per sqm. & BIS \\
\hline Portugal & Residential property prices, new and existing dwellings. & BIS \\
\hline Russia & Residential property prices, existing dwellings, per sqm. & BIS \\
\hline Serbia & Average prices of dwellings in new construction, per sqm. & Nat. Stat. Office \\
\hline Singapore & Average prices of dwellings in new construction, per sqm. & BIS \\
\hline Slovak Rep. & Residential property prices, existing dwellings. & OECD \\
\hline Slovenia & House price index. & OECD \\
\hline South Africa & Residential property price. & BIS \\
\hline Spain & Precio medio del $\mathrm{m} 2$ de la vivienda libre ( $>2$ anos de antiguedad). & OECD \\
\hline Sweden & Real estate price index for one and two dwelling buildings for permanent living. & OECD \\
\hline Switzerland & Real estate price indices. & OECD \\
\hline Taiwan & National House Price Index. & Synyi \\
\hline Thailand & Residential property prices, average of all detached houses, per sqm. & BIS \\
\hline Ukraine & Average Price of Apartments, Kiev, per sqm (US Dollars). & Blagovest \\
\hline UK & Mix-adjusted house price index. & OECD \\
\hline US & Purchase and all-transactions indices. & OECD \\
\hline Uruguay & Precio promedio del metro cuadrado de compraventas, Montevideo (US Dollars). & Nat. Stat. Office \\
\hline
\end{tabular}

Note. See the extended appendix on the sources of house price series extended with historical data. 


\section{B Appendix. Robustness}

Table B.1 Summary Statistics 1990-2006

(a) Advanced Economies

\begin{tabular}{lrrrr}
\hline \hline & House Prices & Equity Prices & Consumption & GDP \\
\hline Mean & $0.7 \%$ & $1.4 \%$ & $0.7 \%$ & $0.7 \%$ \\
Median & $0.8 \%$ & $1.8 \%$ & $0.7 \%$ & $0.7 \%$ \\
St. Dev. & $1.8 \%$ & $8.3 \%$ & $1.0 \%$ & $1.0 \%$ \\
Auto Corr. & 0.5 & 0.4 & 0.1 & 0.2 \\
Pairwise Corr. & 0.1 & 0.6 & 0.1 & 0.2 \\
\hline \hline
\end{tabular}

(b) Emerging Markets

\begin{tabular}{lrrrr}
\hline \hline & House Prices & Equity Prices & Consumption & GDP \\
\hline Mean & $1.2 \%$ & $2.0 \%$ & $1.2 \%$ & $1.0 \%$ \\
Median & $1.0 \%$ & $2.4 \%$ & $1.3 \%$ & $1.3 \%$ \\
St. Dev. & $4.8 \%$ & $14.1 \%$ & $2.7 \%$ & $2.0 \%$ \\
Auto Corr. & 0.3 & 0.2 & 0.1 & 0.2 \\
Pairwise Corr. & 0.1 & 0.3 & 0.1 & 0.1 \\
\hline \hline
\end{tabular}

Note. Averages of country-specific statistics within group. All variables are in log-difference and seasonally adjusted. House prices and equity prices are deflated with CPI (also seasonally adjusted). Real private consumption and real GDP are from the national accounts. Sample period is 1990:Q1 - 2006:Q4. 
Table B.2 SUMmary STATISTICS 1990-2012 (No INTERPOLATED DATA)

(a) Advanced Economies

\begin{tabular}{lrrrr}
\hline \hline & House Prices & Equity Prices & Consumption & GDP \\
\hline Mean & $0.4 \%$ & $0.1 \%$ & $0.5 \%$ & $0.5 \%$ \\
Median & $0.5 \%$ & $1.3 \%$ & $0.6 \%$ & $0.6 \%$ \\
St. Dev. & $1.9 \%$ & $10.1 \%$ & $1.1 \%$ & $1.1 \%$ \\
Auto Corr. & 0.6 & 0.4 & 0.2 & 0.3 \\
Pairwise Corr. & 0.2 & 0.7 & 0.2 & 0.3 \\
\hline \hline
\end{tabular}

(b) Emerging Markets

\begin{tabular}{lrrrr}
\hline \hline & House Prices & Equity Prices & Consumption & GDP \\
\hline Mean & $0.6 \%$ & $0.5 \%$ & $1.1 \%$ & $0.9 \%$ \\
Median & $0.5 \%$ & $1.4 \%$ & $1.2 \%$ & $1.2 \%$ \\
St. Dev. & $4.8 \%$ & $15.0 \%$ & $2.4 \%$ & $2.1 \%$ \\
Auto Corr. & 0.3 & 0.3 & 0.1 & 0.3 \\
Pairwise Corr. & 0.1 & 0.5 & 0.1 & 0.2 \\
\hline \hline
\end{tabular}

Note. Averages of country-specific statistics within group. All variables are in log-difference and seasonally adjusted. House prices and equity prices are deflated with CPI (also seasonally adjusted). Real private consumption and real GDP are from the national accounts. Sample period is longest series available for house prices in 1990:Q1. House price series obtained from interpolation of annual data are dropped. 
Table B.3 SUMmary STATISTICS 1995-2012

(a) Advanced Economies

\begin{tabular}{lrrrr}
\hline \hline & House Prices & Equity Prices & Consumption & GDP \\
\hline Mean & $0.5 \%$ & $0.3 \%$ & $0.5 \%$ & $0.5 \%$ \\
Median & $0.7 \%$ & $1.6 \%$ & $0.6 \%$ & $0.6 \%$ \\
St. Dev. & $1.8 \%$ & $10.4 \%$ & $1.1 \%$ & $1.0 \%$ \\
Auto Corr. & 0.6 & 0.4 & 0.2 & 0.3 \\
Pairwise Corr. & 0.2 & 0.7 & 0.2 & 0.4 \\
\hline \hline
\end{tabular}

(b) Emerging Markets

\begin{tabular}{lrrrr}
\hline \hline & House Prices & Equity Prices & Consumption & GDP \\
\hline Mean & $0.6 \%$ & $0.1 \%$ & $1.1 \%$ & $1.0 \%$ \\
Median & $0.6 \%$ & $1.2 \%$ & $1.2 \%$ & $1.2 \%$ \\
St. Dev. & $4.8 \%$ & $14.1 \%$ & $2.1 \%$ & $1.9 \%$ \\
Auto Corr. & 0.3 & 0.3 & 0.2 & 0.3 \\
Pairwise Corr. & 0.1 & 0.5 & 0.1 & 0.2 \\
\hline \hline
\end{tabular}

Note. Averages of country-specific statistics within group. All variables are in log-difference and seasonally adjusted. House prices and equity prices are deflated with CPI (also seasonally adjusted). Real private consumption and real GDP are from the national accounts. Sample period is longest series available for house prices in 1995:Q1. 


\section{Appendix. Identification}

Consider the following reduced form VAR (with only one lag and no constant or trend for simplicity):

$$
x_{t}=F x_{t-1}+u_{t},
$$

where $x_{t}$ is a $(m \times 1)$ vector of endogenous variables; $F$ is a $(m \times m)$ matrix of coefficients; and $u_{t}$ is a $(m \times 1)$ vector of residuals with variance-covariance matrix $\Sigma_{u}$. The objective is to recover the structural form of the above VAR, i.e.:

$$
A x_{t}=B x_{t-1}+\varepsilon_{t}
$$

where $A$ and $B$ are $(m \times m)$ matrices of coefficients; and $\varepsilon_{t}$ is an $(m \times 1)$ vector of structural residuals with variance-covariance matrix $\Sigma_{\varepsilon}=I$. Note that the reduced form residuals are a linear combination of the structural residuals. Specifically, letting $\tilde{A}=A^{-1}$, we have that $u_{t}=\tilde{A} \varepsilon_{t}$.

If we partition the vector of endogenous variables $x_{t}$ as $\left(G L_{t}^{\prime}, x_{p, t}^{\prime}\right)^{\prime}$-where $G L_{t}$ is global liquidity and $x_{p, t}$ is the $(m-1 \times 1)$ vector of remaining endogenous variables - we can re-write the reduced-form VAR as:

$$
\left[\begin{array}{l}
G L_{t} \\
x_{p, t}
\end{array}\right]=\left[\begin{array}{ll}
f_{11} & f_{12} \\
f_{21} & f_{22}
\end{array}\right]\left[\begin{array}{c}
G L_{t-1} \\
x_{p, t-1}
\end{array}\right]+\left[\begin{array}{cc}
\tilde{a}_{11} & \tilde{a}_{12} \\
\tilde{a}_{21} & \tilde{a}_{22}
\end{array}\right]\left[\begin{array}{c}
\varepsilon_{t}^{G L} \\
\varepsilon_{t}^{x_{p}}
\end{array}\right],
$$

where $f_{11}$ and $\tilde{a}_{11}$ are scalars; $f_{12}$ and $\tilde{a}_{12}$ are $(1 \times m-1)$ vectors; $f_{21}$ and $\tilde{a}_{21}$ are $(m-1 \times 1)$ vectors; $f_{22}$ and $\tilde{a}_{22}$ are $(m-1 \times m-1)$ matrices; and $\varepsilon_{t}^{G L}$ and $\varepsilon_{t}^{x_{p}}$ are the structural residuals associated to global liquidity and the remaining endogenous variables, respectively.

For the sake of argument, let's assume that the structural matrix $\tilde{A}$ is known. Then, we would be able to compute the impulse response to a global liquidity shock. Specifically, the contemporaneous responses of $G L$ and $x_{p}$ to a unit shock to $\varepsilon^{G L}$ would be given by:

$$
\left[\begin{array}{c}
\mathscr{I} \mathscr{R} \mathscr{F}_{0}^{G L} \\
\mathscr{I} \mathscr{R} \mathscr{F}_{0}^{x_{p}}
\end{array}\right]=\left[\begin{array}{c}
\tilde{a}_{11} \\
\tilde{a}_{21}
\end{array}\right]
$$

which, since the model is linear, can be normalized to:

$$
\left[\begin{array}{c}
\mathscr{I} \mathscr{R} \mathscr{F}_{0}^{G L} \\
\mathscr{I} \mathscr{R} \mathscr{F}_{0}^{x_{p}}
\end{array}\right]=\left[\begin{array}{c}
1 \\
\tilde{a}_{21} \\
\tilde{a}_{11}
\end{array}\right]
$$

Finally, the impulse response functions at longer horizons can be computed as:

$$
\mathscr{I} \mathscr{R}_{\mathscr{F}}{ }_{n}=F^{n-1} \cdot \mathscr{I} \mathscr{R}_{\mathscr{F}}{ }_{n-1} \quad \text { for } n=2, \ldots, N \text {. }
$$

Note that if we are interested in computing the impulse responses to the global liquidity shock only we do not need to know all the coefficients of $\tilde{A}$, but rather only the elements of the first column of $\tilde{A}$, namely $\tilde{a}^{1}$.

We now consider the case of $\tilde{A}$ unknown. To achieve identification, we follow the external instrument identification approach pioneered by Stock and Watson (2012) and Mertens and Ravn 
(2013). Let $u^{G L}$ and $u^{x_{p}}$ be the OLS estimates of the reduced form residuals in (C.1). Also, let $Z_{t}$ be a $(z \times 1)$ vector of instrumental variables that satisfy:

$$
\begin{aligned}
\mathbb{E}\left[\varepsilon^{G L} Z_{t}^{\prime}\right] & =\phi, \\
\mathbb{E}\left[\varepsilon^{x_{p}} Z_{t}^{\prime}\right] & =0,
\end{aligned}
$$

i.e., the instruments are correlated with the global liquidity shock $\left(\varepsilon^{G L}\right)$ but are orthogonal to all the other domestic shocks (the elements of $\varepsilon^{x_{p}}$ ). We can obtain consistent estimates of $\tilde{a}^{1}$ from the two-stage least squares regression of $u^{x_{p}}$ on $u^{G L}$ using $Z_{t}$ as instruments. In other words, since the reduced form residuals of the global liquidity equation $\left(u_{t}^{G L}\right)$ are an imperfect measure of true structural shock $\left(\varepsilon^{G L}\right)$, in the first stage we regress them on the set of instruments $\left(Z_{t}\right)$ :

$$
u_{t}^{G L}=\beta Z_{t}+\xi_{t}
$$

to construct the fitted values $\hat{u}_{t}^{G L}$. Then we regress the reduced form residuals of the domestic equations $\left(u_{t}^{x_{p}}\right)$ on the fitted values $\left(\hat{u}_{t}^{G L}\right)$ to get a consistent estimate of the ratio $\tilde{a}_{21} / \tilde{a}_{11}$ :

$$
u_{t}^{x_{p}}=\frac{\tilde{a}_{21}}{\tilde{a}_{11}} \hat{u}_{t}^{G L}+\zeta_{t},
$$

where note that $\hat{u}_{t}^{G L}$ is orthogonal to $\zeta_{t}$ under the assumption that $E\left[\varepsilon^{x_{p}} Z_{t}^{\prime}\right]=0$.

Finally, we can use the OLS estimates of the matrix $F$ to compute the impulse response functions of all variables to a global liquidity shock using the formula in (C.5). 